\title{
Ozone-driven daytime formation of secondary organic aerosol containing carboxylic acid groups and alkane groups
}

\author{
S. Liu ${ }^{1}$, D. A. Day ${ }^{1}{ }^{*}$, J. E. Shields ${ }^{1}$, and L. M. Russell ${ }^{1}$ \\ ${ }^{1}$ Scripps Institution of Oceanography, University of California, San Diego, La Jolla, California, USA \\ *now at: Cooperative Institute for Research in the Environmental Sciences, University of Colorado, Boulder, Colorado, USA
}

Received: 18 February 2011 - Published in Atmos. Chem. Phys. Discuss.: 2 March 2011

Revised: 29 June 2011 - Accepted: 9 August 2011 - Published: 16 August 2011

\begin{abstract}
Carboxylic acids are present in substantial quantities in atmospheric particles, and they play an important role in the physical and chemical properties of aerosol particles. During measurements in coastal California in the summer of 2009, carboxylic acid functional groups were exclusively associated with a fossil fuel combustion factor derived from factor analysis of Fourier transform infrared spectroscopic measurements and closely correlated with oxygenated organic factors from aerosol mass spectrometry measurements. The high fraction of acid groups and the high ratio of oxygen to carbon in this factor suggest that this factor is composed of secondary organic aerosol (SOA) products of combustion emissions from the upwind industrial region (the ports of Los Angeles and Long Beach). Another indication of the photochemically-driven secondary formation of this combustion-emitted organic mass (OM) was the daytime increase in the concentrations of acid groups and the combustion factors. This daytime increase closely tracked the $\mathrm{O}_{3}$ mixing ratio with a correlation coefficient of 0.7 , indicating $\mathrm{O}_{3}$ was closely associated with the SOA maximum and thus likely the oxidant that resulted in acid group formation. Using a pseudo-Lagrangian framework to interpret this daytime increase of carboxylic acid groups and the combustion factors, we estimate that the carboxylic acid groups formed in a 12-h daytime period of one day ("Today's SOA") accounted for $25-33 \%$ of the measured carboxylic acid group mass, while the remaining $67-75 \%$ (of the carboxylic acid group mass) was likely formed 1-3 days previously (the "Background SOA"). A similar estimate of the daytime increase in the combustion factors suggests that "Today's SOA" and the "Background SOA" respectively contributed 25-50\% and $50-75 \%$ of the combustion factor (the "Total SOA"), for a "Total SOA" contribution to the OM of $60 \%$ for the project
\end{abstract}

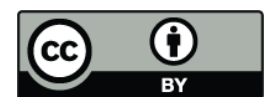

Correspondence to: L. M. Russell (lmrussell@ucsd.edu) average. Further, size-resolved spectrometric and spectroscopic characterization of the particle OM indicate that the majority of the OM formed by condensation of gas-phase oxidation products. This unique set of measurements and methods to quantify and characterize photochemically and ozone-linked carboxylic acid group formation provide independent and consistent assessments of the secondary fraction of $\mathrm{OM}$, which could result from second generation products of the oxidation of gas-phase alkane (molecules).

\section{Introduction}

Organic compounds typically account for $10-70 \%$ of dry particle mass (Turpin et al., 2000). Understanding the chemistry of particle-phase organic compounds is important for assessing the effects of aerosol particles on air quality, human health, and climate change (Fuzzi et al., 2006). The major organic components identified in ambient particles include alkane (saturated C-C-H), carboxylic acid $(\mathrm{C}(\mathrm{O}) \mathrm{OH})$, hydroxyl $(\mathrm{C}-\mathrm{OH})$, amine $(\mathrm{C}-\mathrm{NH})$, and non-acid carbonyl $(\mathrm{C}=\mathrm{O})$ functional groups (Maria et al., 2002; Liu et al., 2009; Russell et al., 2009a; Ge et al., 2011; Jaoui et al., 2004; Pietrogrande et al., 2010), among which alkane and carboxylic acid functional groups, taken together, often account for more than $70 \%$ of the OM (Russell et al., 2011). Alkane groups, a large component of ambient organic compounds (Maria et al., 2002), are typically associated with primary gas and particle-phase emissions that originate from fossil fuel combustion emissions, including vehicular exhaust (Rogge et al., 1993) and coal burning (Wang et al., 2009). In addition to being prevalent in primary emissions, alkane groups are found in many oxygenated secondary organic products, e.g. $\beta$-pinene oxidation products might include norpinic acid (Yu et al., 1999), which has two oxygenated groups and five hydrogenated carbons, each with one to three $\mathrm{C}-\mathrm{H}$ bonds. Carboxylic acid groups are observed in urban, rural, and remote

Published by Copernicus Publications on behalf of the European Geosciences Union. 
atmospheric particles and sometimes account for more than $30 \%$ of OM (Grosjean et al., 1978; Kawamura and Gagosian, 1987; Kawamura, 1993; Fraser et al., 2002; Wang et al., 2002; Sullivan and Weber, 2006; Claeys et al., 2007; Russell et al., 2009a; Wang et al., 2009; Zhang et al., 2010). Because many carboxylic acids are highly soluble and tend to absorb water under high relative humidity (RH), they could affect radiative (e.g. light scattering) and chemical (e.g. aqueousphase reaction) properties of ambient particles.

Carboxylic acids have been frequently observed in atmospheric particles since 1970s (Schuetzle et al., 1975; Cronn et al., 1977; Satsumabayashi et al., 1989; Satsumabayashi et al., 1990; Kawamura and Ikushima, 1993; Rogge et al., 1993). In these measurements, carboxylic acid concentration either correlated to solar radiation or correlated to oxidant concentration (mostly ozone), suggesting they are formed in the atmosphere during photochemical processes. For example, enhanced abundance of ambient carboxylic acids in summer and in the afternoon suggests that carboxylic acids are secondary (Kawamura and Ikushima, 1993; Kawamura and Yasui, 2005). Although primary emission of carboxylic acids from engine exhaust and meat cooking were identified in a few studies (Kawamura and Kaplan, 1987; Rogge et al., 1991), the lack of correlation of carboxylic acids to traffic emission and meat cooking tracers suggest that these primary acid sources may not reflect a majority of carboxylic acid mass. Recent laboratory studies have shown condensedphase carboxylic acid groups formed as SOA from anthropogenic and biogenic precursors (Yu et al., 1999; Fisseha et al., 2004; Claeys et al., 2007). Aqueous-phase or in-cloud formation of carboxylic acids has been suggested by several field studies and modeling simulations (Blando and Turpin, 2000; Warneck, 2003; Ervens et al., 2004; Yu et al., 2005; Sullivan and Prather, 2007; Altieri et al., 2006), indicating carboxylic acid groups can be formed through various processes under different ambient conditions. Recently, reactions of gas-phase alkanes (molecules) have been studied by several research groups (Hallquist et al., 2009; Lim and Ziemann, 2009; Miracolo et al., 2010; Presto et al., 2010), which suggest gas-phases alkane (molecules) could be a precursor of carboxylic acid group formation (Russell et al., 2011).

Despite an increasing number of studies on carboxylic acids in recent years, the formation mechanism of carboxylic acids and other SOA components are still poorly understood, making identification of ambient SOA controversial. The organic carbon (OC) to elemental carbon (EC) ratio has been used to estimate SOA by assuming an average OC/EC from emission source measurements. OC/EC exceeding the average OC/EC is assumed to be SOA (Turpin et al., 1991). The SOA mass estimated from this method is highly uncertain, since OC/EC is highly variable from source to source (Gray et al., 1986) and the average OC/EC is dependent on meteorological conditions. Another approach is to identify SOA products from individual precursors (Yu et al., 1999). This method requires detection of SOA by molecular level specia- tion and known SOA formation mechanisms, which are often not available.

In this work, we compare the contributions of carboxylic acid group and other oxygenated organic groups that can be attributed to photochemical SOA formation in the atmosphere. We use factors identified from the Positive Matrix Factorization (PMF) analyses on the complementary Fourier Transform Infrared (FTIR) spectroscopy and Aerosol Mass Spectrometry (AMS) measurements to separate organic components based on their sources, so that the SOA formation for each source can be considered separately. The oxygenated nature of the fossil fuel combustion factors is used to provide an initial estimate of the total contribution of acid groups to SOA. A second estimate of SOA formation is provided by using a pseudo-Lagrangian framework to identify the fraction of SOA formed in a single day ("Today's SOA"). In addition, we use the size distribution of acid groups to provide evidence of the mechanism by which the SOA forms. By comparing the extent to which these three methods are consistent, this study provides both an evaluation of the contribution of acid groups to SOA and evidence for the timescale, precursors, and oxidants involved in SOA formation.

\section{Sample collection and instrumentation}

Submicron particles were continuously collected at the Scripps Pier ( $8 \mathrm{~m}$ above sea level (a.s.1.)) in La Jolla $\left(32.87^{\circ} \mathrm{N}, 117.25^{\circ} \mathrm{W}\right)$, California, from 15 August to $1 \mathrm{Oc}-$ tober 2009. Instruments were deployed in a temperaturecontrolled container at the end of the pier $(300 \mathrm{~m}$ west of the shoreline) and shared a common $3 / 8^{\prime \prime}$ o.d. stainless steel inlet. Submicron particles were separated by a $\mathrm{PM}_{1}$ cyclone and were collected on four filters daily for the time periods: 06:00-10:00 PST, 10:00-14:00 PST, 14:00-18:00 PST, and 18:00-06:00 PST (the next day) Pacific Standard Time (PST, one hour earlier than local daylight time), representing morning, midday, afternoon, and nighttime samples, respectively. A 24-h sample was simultaneously collected in parallel with shorter samples for each day. $37 \mathrm{~mm}$ Teflon filters (Teflo, Pall Inc., Ann Arbor, MI) were used for the FTIR analysis performed using a Bruker Tensor 27 FTIR Spectrometer with a DTGS detector (Bruker, Waltham, MA). Samples were frozen during storage to reduce desorption. Each Teflon filter was scanned before and after sampling using the FTIR and the pre-scanned spectrum was subtracted from the post-scanned spectrum to correct for variability in the polytetrafluoroethylene absorption of the Teflon filters. An automated algorithm was used to conduct spectrum subtraction, baselining, peak-fitting, and error estimation (Russell et al., 2009a). Mass concentrations of alkane, carboxylic acid, hydroxyl, amine, non-acid carbonyl, organonitrate, alkene, and aromatic functional groups were quantified using previously reported algorithms and standards (Russell et al., 2009a; Day et al., 2010). 
Concentrations of non-refractory organics, sulfate, ammonium, nitrate, and chloride were measured using a quadrupole AMS (Aerodyne, Billerica, MA). In this instrument, particles passed through a $100 \mu \mathrm{m}$ orifice were focused by an aerodynamic lens followed by vaporization $\left(600^{\circ} \mathrm{C}\right)$ and ionization at the entrance of a quadropole mass spectrometer. Particle size is measured by time-of-flight between a rotating chopper, which modulates the particle beam (Jayne et al., 2000). The "mass spectrum" (MS) mode and the "time-of-flight" (TOF) mode alternated during the measurements. Complete mass spectra (1-300 amu) and size distributions for selected mass fragments were stored at 5-min resolution. Transmission efficiency was approximately $100 \%$ for 60 to $600 \mathrm{~nm}$ particles (Jayne et al., 2000). Dry ammonium nitrate particles $(350 \mathrm{~nm})$ were used to calibrate the ionization efficiency weekly. Collection efficiency (CE) of the AMS was assigned to each 5-min organic and inorganic measurement to correct for particle loss due to bouncing off of the vaporizer. The CE was determined as a linear function of the ammonium to sulfate molar ratio, with 0.45 and 1 corresponding to ratios $\geq 1$ and 0 , respectively (Quinn et al., 2006). Another commonly used method for CE correction is to use $\mathrm{CE}=0.5$, when no other simultaneous measurements are available. In this study, the sulfate-based correction resulted in a greater correlation of the FTIR and the AMS OM than using a constant CE of 0.5. Therefore, the sulfate-based method is used in this study. The campaign average ammonium to sulfate molar ratio was $1.9 \pm 1.2$, and the $C E$ was 0.45 for approximately $85 \%$ of the measurements.

Single particles were impacted on $\mathrm{Si}_{3} \mathrm{~N}_{4}$ windows on 27 August and 4, 14, 20, and 22 September, 2009. Four samples were collected $(15-30 \mathrm{~min})$ on these days for periods overlapping the four FTIR filter sampling periods. Samples were stored at temperatures below $0^{\circ} \mathrm{C}$ before analysis at the Advanced Light Source (Lawrence Berkeley National Laboratory, CA) on beamline 5.3.2 (Kilcoyne et al., 2003; Liu et al., 2009). Single particle image and K-edge $\mathrm{X}$-ray absorption spectrum were acquired using a combination of Scanning Transmission X-ray Microscopy (STXM) and Near-Edge X-ray Absorption Fine Structure (NEXAFS) spectroscopy. Organic functional groups (including alkane, hydroxyl, ketone, alkene, and carboxylic acid groups) and inorganic potassium and carbonate of carbon-containing single particles were measured (Russell et al., 2002; Maria et al., 2004). Particle size, image, and organic functional group abundance were analyzed using an automated algorithm described by Takahama et al. (2010).

Carbon monoxide (CO) dry air mole fractions were measured by a newly installed Horiba APMA-370 NDIR analyzer. Air was continuously pumped through a sampling line ( $400 \mathrm{~m} ; 1 / 2^{\prime \prime}$ Dekabon) with an inlet $20 \mathrm{~m}$ a.s.l. Measurements were reported as 5-min averages, initially using the factory calibration. The instrument was subsequently calibrated against standards on the NOAA/ESRL 2004 CO calibration scale, and the field campaign results were recalcu- lated based on the measurement of a whole air reference cylinder that was measured during the field campaign and also during the NOAA standard calibrations. In the absence of a more thorough real-time calibration, we estimate that the precision of the 5-min averaged $\mathrm{CO}$ measurements is 5-10 ppb. Ozone $\left(\mathrm{O}_{3}\right)$ mixing ratio was monitored using a Thermo Environmental Instruments (TEI) 49C analyzer and measurements were recorded as 1-min averages. The $\mathrm{O}_{3}$ measurements were not calibrated during the campaign, so only the concentrations relative to the campaign average are reported.

\section{Results}

This section describes the meteorological conditions under which carboxylic acid groups are formed, the composition of organic mass quantified by FTIR, AMS, and STXMNEXAFS, and the components contributing to organic mass identified from factor analysis. The daily variations in organic functional groups, AMS measured components, and $\mathrm{O}_{3}$ mixing ratio are then compared.

\subsection{Meteorological conditions during the sampling period}

The sampling period was characterized by consistent temperature and RH with the averages and standard deviations being $20.2 \pm 2.5^{\circ} \mathrm{C}$ and $79.3 \pm 8.6 \%$, respectively. Temperature peaked in the afternoon and showed a minimum in the early morning, anti-correlating with RH. Photosynthetically active radiation peaked at noon. Land-sea breeze circulation was observed during the measurement period and was consistent with previous studies (Hughes et al., 2007). In general, surface wind shifted at about 07:00 PST from offshore to onshore wind and at 22:00 PST from onshore to offshore wind (Fig. 1b).

Back trajectories were calculated hourly using the Hybrid Single-Particle Lagrangian Integrated Trajectory (HYSPLIT) model (Draxler and Rolph, 2003; Rolph, 2003) at $200 \mathrm{~m}$ and were used to determine the origin of air masses. The FTIR filter samples were grouped into sectors representing the origin of air masses (Fig. 1a) as indicated by the top bars in Fig. 2a. Each air mass sector (along with consistent daytime onshore flow) allows analysis of particles originating from the same source region (most frequently the ports of Los Angeles and Long Beach region) for 1-3 consecutive days. To further investigate likely sources of OM, potential source contribution function (PSCF) was applied to the factors resulted from factor analysis. PSCF classifies the back trajectories as "high" and "low" by concentration of the target component and calculates the probability that a source is located at a particular region (Pekney et al., 2006). Examples of PSCF results are shown in Fig. A1. 

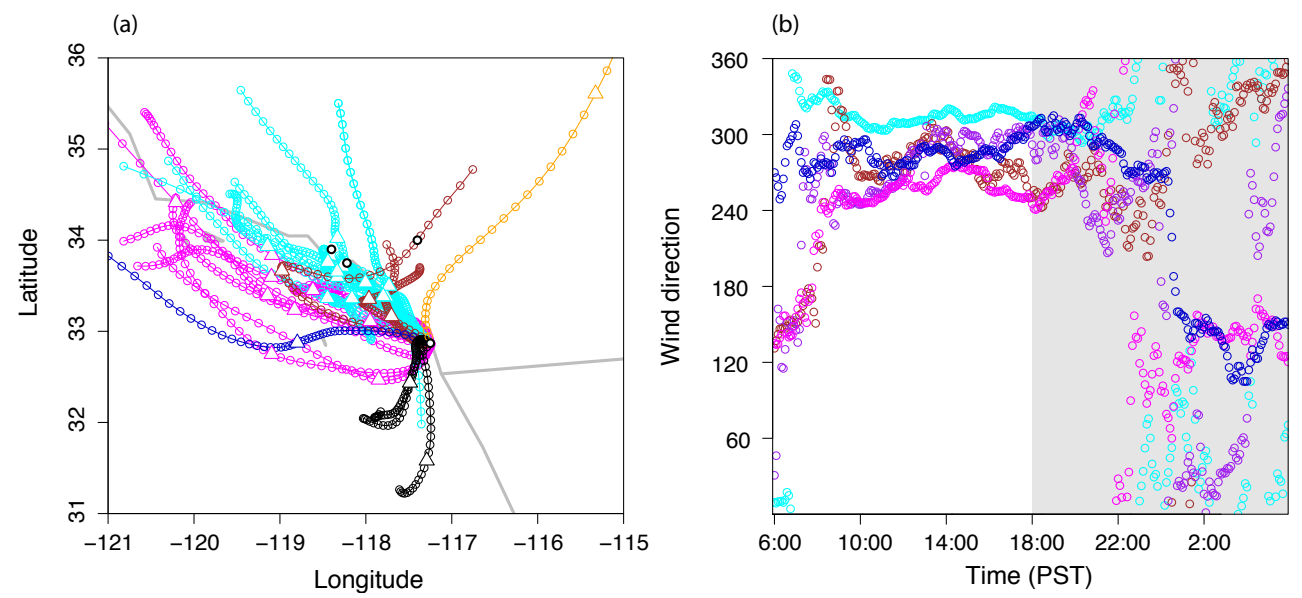

Fig. 1. (a): Averaged 48-h back trajectories for each day (daytime only) representing Los Angeles-Long Beach (cyan; air mass coming from Los Angeles and Long Beach regions), Riverside (brown; air mass originating from Riverside vicinity), Inland (orange; easterly/northeasterly air mass), Tijuana-Ensenada (black; southerly air mass), Mixed coastal (magenta; northerly air mass coming along the coast of California), and Ocean (dark blue; westerly air mass) air mass sectors during the campaign. The triangle in each trajectory indicates 24-h before the air mass arrived at the sampling site. The black circles (from top to bottom) indicate Riverside, Los Angeles, Los Angeles - Long Beach port, and the sampling site; (b) vector-averaged diurnal profile of wind direction ( 0 degree represents wind coming from north) for the air mass sectors specified in (a). Shaded areas indicate nighttime periods.

\subsection{Organic and inorganic composition of submicron particles}

Table 1 summarizes the campaign average concentrations of the FTIR and AMS-measured components. Figure 2a shows the time series and the average fraction of organic functional groups measured by FTIR. The OM concentration varied from 0.39 to $11 \mu \mathrm{g} \mathrm{m}^{-3}$ with an average concentration of $3.3 \pm 1.9 \mu \mathrm{g} \mathrm{m}^{-3}$, which was comparable to the OM concentration in the summer of 2008 (Hawkins and Russell, 2010a) and about twice the OM concentration measured in the winter of 2009 (Day et al., 2010) at the same site. Alkane functional group concentration was $1.5 \pm 1.1 \mathrm{\mu g} \mathrm{m}^{-3}$ and contributed $47 \%$ of the OM. Carboxylic acid functional groups accounted for $34 \%$ of the OM with an average concentration of $1.1 \pm 0.8 \mu \mathrm{g} \mathrm{m}^{-3}$. The concentration of hydroxyl functional groups was $0.40 \pm 0.24 \mathrm{~g} \mathrm{~m}^{-3}$, accounting for $12 \%$ of the OM. Amine, non-acid carbonyl, and organonitrate functional groups contributed small fractions to the OM (3\%, $2 \%$, and $2 \%$, respectively). Alkene and aromatic functional groups were below detection limit for all samples and each was estimated to account for no more than $4 \%$ of the OM. These two functional groups were excluded from the analyses in this study. Samples associated with different air mass sectors had similar organic functional group compositions but differed in mass concentration. The Los AngelesLong Beach port and the Riverside sectors contain significantly higher OM, indicating transport of pollutants from these heavily polluted regions to the sampling site, which is consistent with the findings of Ault et al. (2009). Each "day" was defined as " $06: 00$ to $06: 00$ PST". 32 out of 47 days were
Table 1. Campaign average and standard deviation of FTIRmeasured OM, FTIR organic functional group concentrations, and AMS-measured OM, sulfate, ammonium, nitrate, and chloride concentrations in $\mu \mathrm{g} \mathrm{m}^{-3}$. Functional group OM mass fractions (for FTIR) and component mass fractions of $\mathrm{PM}_{\mathrm{AMS}}$ (for AMS) are shown in the parentheses.

\begin{tabular}{lll}
\hline FTIR & OM & $3.3 \pm 1.9$ \\
& Alkane & $1.5 \pm 1.1(47 \%)$ \\
& Carboxylic Acid & $1.1 \pm 0.77(34 \%)$ \\
& Hydroxyl & $0.40 \pm 0.24(12 \%)$ \\
& Amine & $0.11 \pm 0.09(3 \%)$ \\
& Non-Acid Carbonyl & $0.06 \pm 0.21(2 \%)$ \\
& Organonitrate & $0.07 \pm 0.12(2 \%)$ \\
\hline \multirow{2}{*}{ AMS } & OM & $3.9 \pm 3.0(43 \%)$ \\
& Sulfate & $3.1 \pm 1.7(39 \%)$ \\
& Ammonium & $1.0 \pm 0.53(12 \%)$ \\
& Nitrate & $0.43 \pm 0.49(5 \%)$ \\
& Chloride & $0.03 \pm 0.05(0.3 \%)$
\end{tabular}

associated with a single air mass sector during the daytime. These days (as indicated by the top green bars in Fig. 2a) are included in an analysis of their diurnal cycles.

The OM fraction of carboxylic acid groups in single particles, calculated as carboxylic acid group absorption normalized by the sum of absorption of all functional groups from the X-ray spectra, are $42 \pm 14 \%$ for the morning particles and $38 \pm 17 \%$ for the afternoon particles. These values are comparable to the carboxylic acid group fraction of $34 \%$ from the submicron FTIR measurement, given the uncertainties 


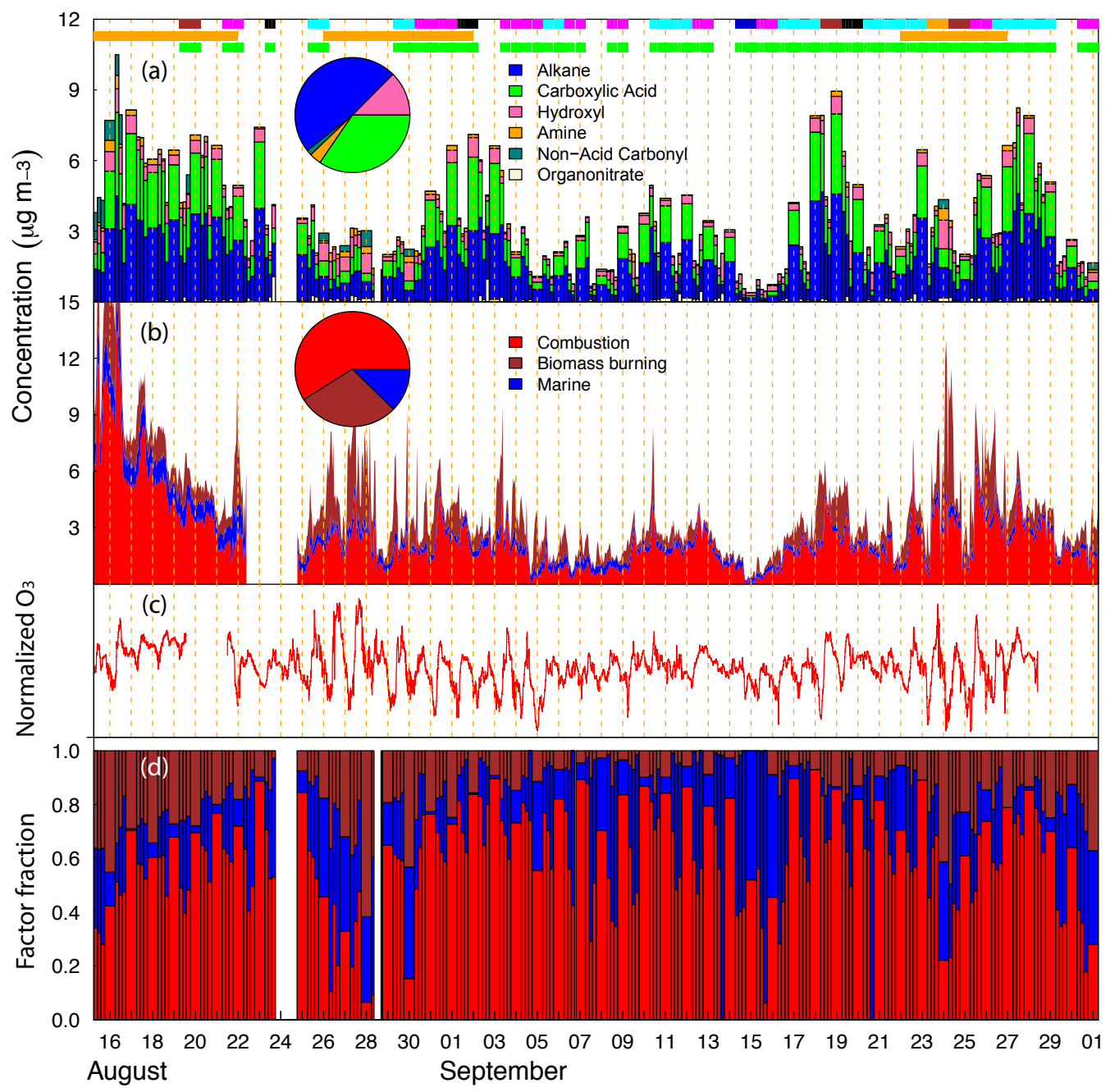

Fig. 2. (a) Time series of organic functional group concentrations measured by the FTIR; sectors are indicated by the top color bars (same colors as in Fig. 1), for which the sector associated with each FTIR sample was determined as the air mass origin shown by the majority $(>80 \%$ ) of the back trajectories during the sampling time; top brown bars indicate fire periods corresponding to the La Brea fire (in Santa Barbara County), the Station fire (in Los Angeles County), and the Guiberson fire (in Ventura County), respectively (from left to right); top green bars indicate samples that were used for diurnal profile analysis. (b) Time series of AMS factors identified by PMF analysis. The inner pie charts in (a) and (b) respectively show campaign average compositions of FTIR components and AMS factors. (c) Time series of normalized $\mathrm{O}_{3}$ (normalized by campaign average) mixing ratio. (d) Mass fractions of the FTIR combustion factor (red), the biomass burning factor (brown), and the marine factor (blue) during the measurement.

and approximations in both methods. There was no measurable difference in the number or mass fraction of carboxylic acid groups in the afternoon particles compared to the morning particles (likely due to the small number of particles (37 in total) that could be analyzed with the limited beamtime available), but the results support the presence of carboxylic acid groups in submicron particles, as expected for SOA formation (Claeys et al., 2007). Further, it is worth noting that acid groups are prevalent throughout the particles, rather than being limited to surface coatings.
The non-refractory particle mass concentration measured by the AMS (which is an estimate of submicron PM and de-

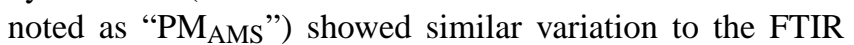
OM concentration (Fig. 2b), indicating common sources or formation pathways of organic and inorganic compounds. Non-refractory OM (nrOM) was the largest component of $\mathrm{PM}_{\mathrm{AMS}}(43 \%)$. Sulfate concentration was $3.1 \pm 1.7 \mu \mathrm{g} \mathrm{m}^{-3}$ and accounted for $39 \%$ of $\mathrm{PM}_{\mathrm{AMS}}$. Ammonium and nitrate contributed $12 \%$ and $5 \%$ of $\mathrm{PM}_{\mathrm{AMS}}$, respectively. Only nonrefractory species of chloride were measured by the AMS, and these accounted for a negligible amount of PM $_{\text {AMS }}$ with a mass fraction of $0.3 \%$ (Table 1). 
Table 2. Concentration and composition of PMF factors identified from the FTIR and the AMS measurements. Colors in the pie charts indicate alkane (blue), carboxylic acid (green), hydroxyl (hot pink), amine (orange), and non-acid carbonyl (teal) functional groups. Mass fractions of the factors are shown in the parentheses.

\begin{tabular}{lllll}
\hline & & combustion & biomass burning & marine Origin \\
\hline \multirow{2}{*}{ FTIR } & Concentration $\left(\mu \mathrm{g} \mathrm{m}^{-3}\right)$ & $3.0(62 \%)$ & $0.88(18 \%)$ & $0.97(20 \%)$ \\
& O/C & 0.46 & 0.48 & 1.04 \\
& & & \\
& & & & \\
\hline \multirow{2}{*}{ AMS } & Composition & & & $0.51(13 \%)$ \\
& $(m / z 44) / \mathrm{OM}$ & $26 \%$ & $5 \%$ & $2.6 \%$ \\
& $(\mathrm{~m} / \mathrm{z} 60) / \mathrm{OM}$ & $0.1 \%$ & $0.1 \%$ & $0.6 \%$ \\
& $(\mathrm{~m} / \mathrm{z} 44) /(\mathrm{m} / \mathrm{z} 43)$ & 7.5 & 0.6 & 1.5 \\
& $(\mathrm{~m} / \mathrm{z} 44) /(\mathrm{m} / \mathrm{z} 5 \mathrm{~s})$ & 146 & 2.7 & 3.6 \\
\hline
\end{tabular}

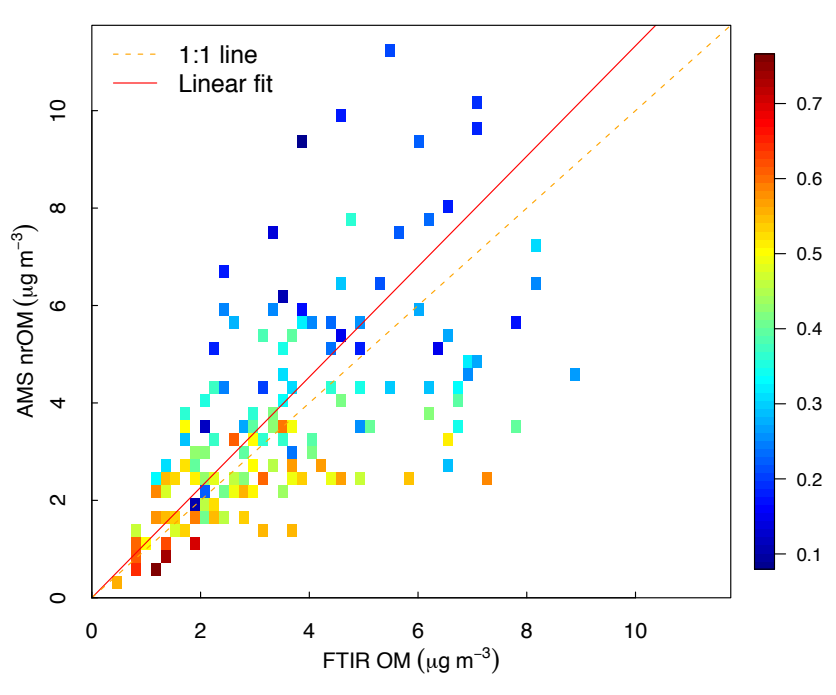

Fig. 3. Comparison of OM measured by the FTIR and the AMS. Colors indicate sulfate mass fraction of $\mathrm{PM}_{\mathrm{AMS}}$. Correlation coefficients for high sulfate mass samples (mass fraction $>20 \%$ ) and low sulfate mass samples (sulfate fraction $<20 \%$ ) are 0.8 and 0.6 , respectively.

The FTIR and AMS-measured OM compared reasonably well as shown in Fig. 3. The slope (1.1) and correlation coefficient $(r=0.7)$ of the OM correlation in this study fall into the typical ranges of the FTIR and AMS-measured OM comparison as summarized by Russell et al. (2009b) from eight previous field campaigns. These values are comparable to the average slope (1.1) and $r$ (0.67) derived from the Scripps Summer 2008 and the Scripps Winter 2009 projects (Russell et al., 2009b). Pearson's correlation coefficient for a reduced major axis regression is used in this study. For samples associated with low sulfate fractions, the trend becomes more scattered from the 1:1 line and the sulfate-based CE has better agreement when sulfate accounts for more than $20 \%$ of $\mathrm{PM}_{\mathrm{AMS}}$. This is consistent with the fact that the sulfate-based
CE used here was developed for ambient samples associated with relatively high sulfate fractions that were about $40 \%$ on average (Quinn et al., 2006).

\subsection{Identification of sources contributing to the organic mass}

PMF (Paatero and Tapper, 1994) can be used to separate the contributions of different sources, each with characteristic compositions, to the multi-component mixtures in ambient organic and inorganic particles (Pekney et al., 2006). We applied PMF to the FTIR spectra and the AMS-measured organic fragment concentrations separately to identify robust, linearly-independent components that compose the OM (Lanz et al., 2007; Russell et al., 2009a).

Identification of the factors is described in detail in Appendix A. The factor composition and concentration are summarized in Table 2. In brief, a combustion factor, a biomass burning factor, and a marine-derived factor were identified from both the FTIR and the AMS PMF analyses, representing fossil fuel combustion, biomass burning, and marine sources, respectively. The reconstructed OM (the sum of the three factors) from the FTIR and the AMS PMF analyses correlated with $r=0.7$ and a slope of 1.1 (with the FTIR OM $10 \%$ higher). The combustion factors dominated the OM (approximately $60 \%$ ) from both analyses (Tables 2 and 3) and the time series correlated to each other with $r=0.5$ and a slope of 1.2 (FTIR factor OM was $20 \%$ higher). The large fraction of carboxylic acid groups in the FTIR combustion factor $(42 \%)$ and the dominance of $m / z 44$ (26\% of OM) in the AMS combustion factor suggest that the combustion factors represent photochemically processed products of vapor emissions, most likely from the Los Angeles and Long Beach regions. The biomass burning factors resulting from the FTIR and the AMS measurements correspond to the three largest fires occurred in Southern California during the sampling period: the Station fie (in Los Angeles County), the La Brea fire (in Santa Barbara County), and the Guiberson 

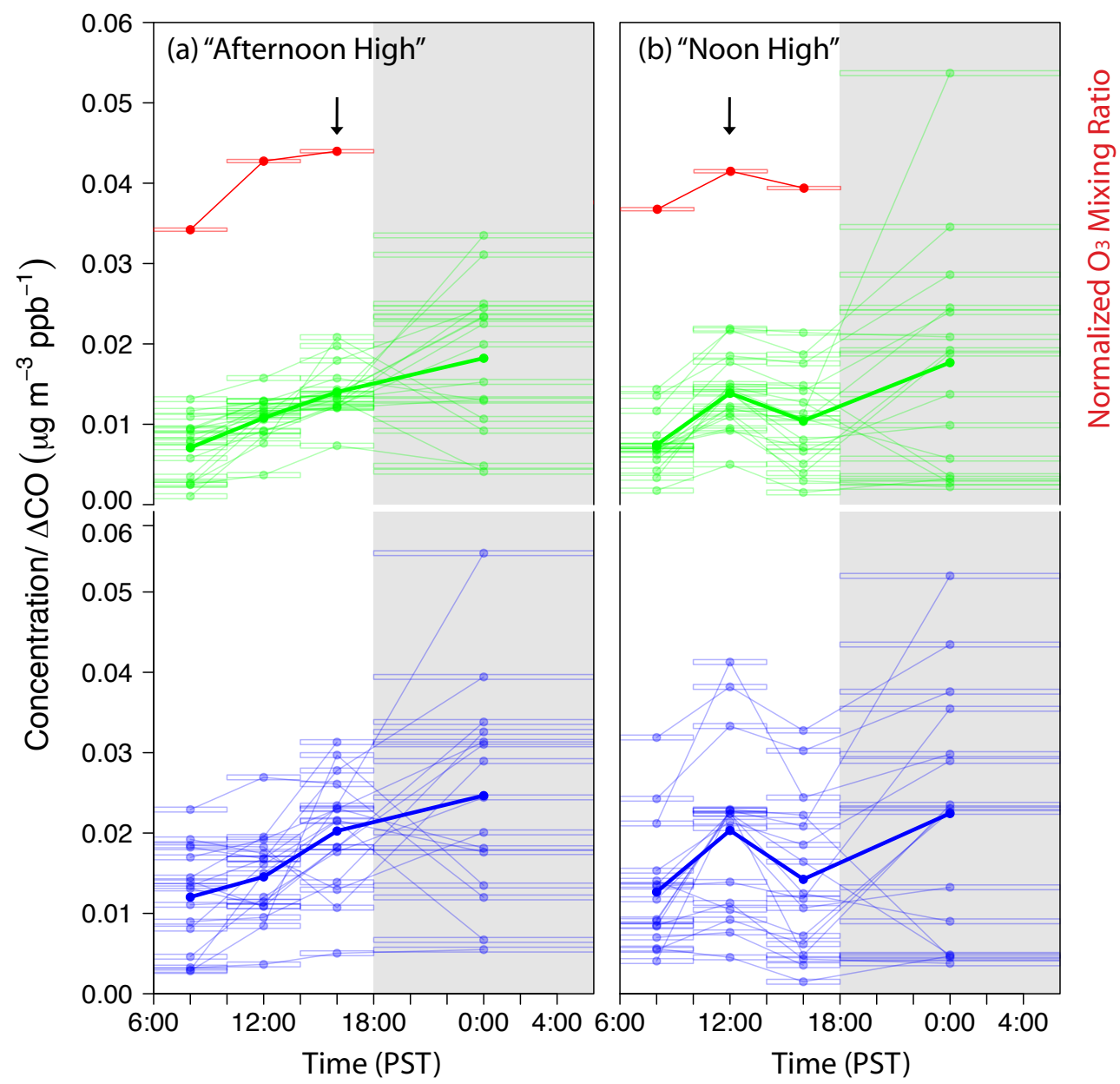

Fig. 4. Diurnal cycles of normalized carboxylic acid group concentrations (green; top part in each panel) and alkane group concentrations (blue; bottom part in each panel) divided into (a) "Afternoon High" and (b) "Noon High" types. Each rectangle represents one FTIR sample with the length of the rectangle indicating the sampling duration. The lines connecting the rectangles show samples collected in the same day. The thinner rectangles and lines represent daily diurnal profiles, while the thicker lines show the averages for the days in the corresponding panel. The red dashed lines represent average diurnal profiles of normalized $\mathrm{O}_{3}$ mixing ratio for the days in each panel. The arrows indicate daytime peak concentration in each panel. Shaded areas indicate nighttime periods corresponding to the FTIR nighttime samples, which were excluded from the diurnal cycle analyses.

fire (in Ventura County). The FTIR and AMS biomass burning factors correlated with $r=0.7$ and slope $=0.9$ (FTIR factor $\mathrm{OM}$ was $10 \%$ lower). The OM fractions of the two biomass burning factors agreed with less than $10 \%$ difference, well within the expected accuracies of both FTIR and AMS OM. The two marine factors correlated to each other with $r=0.5$, with the FTIR factor OM higher by a factor of 2.1. The weaker correlation and the lower mass of the AMS marine factor may be caused by a low transmission efficiency for organic compounds on $\mathrm{NaCl}$ particles as well as a lack of marine-aerosol specific fragments in the AMS measurements. Alternatively it could result from lower absorptivity of carbohydrate hydroxyl groups relative to the hydroxyl standards employed in the quantification algorithm (Russell et al., 2009a). In summary, the factors identified by PMF analyses of the FTIR and the AMS measurements agreed well and the mass differences were within $30 \%$ for the total $\mathrm{OM}$, the combustion factors, and the biomass burning factors. The good agreement shows the consistency of the measurements and the robustness of the identified factors.

\subsection{Diurnal cycles of organic and inorganic components}

Diurnal variations of organic functional groups, organic and inorganic mass fragments, and the PMF factors are discussed in this section. For the diurnal cycle analyses, the concentrations were normalized by the enhancement of carbon monoxide $(\triangle \mathrm{CO})$ mixing ratio (with respect to the background or unpolluted $\mathrm{CO}$ mixing ratio measured at the site during the study) for the FTIR and the AMS measurements. 
This background $\mathrm{CO}$ mixing ratio was determined as the $\mathrm{y}$ intercept of the linear regression of CO versus OM (DeCarlo et al., 2008), which differed slightly for the FTIR OM and the AMS nrOM at $89 \mathrm{ppb}$ and $80 \mathrm{ppb}$, respectively. The difference of the two intercepts results from the larger AMS $\operatorname{nrOM}(10 \%$ higher than the FTIR OM). Since the difference of the two intercepts is small relative to the ambient variations (which had a standard deviation of $71 \mathrm{ppb}$ ), an average value of $85 \mathrm{ppb}$ was used as the background $\mathrm{CO}$ mixing ratio for both the FTIR and the AMS measurements. Normalizing the concentration by $\triangle \mathrm{CO}$, which does not react significantly on timescales of a few days, is used to separate the variations caused by the change of combustion source strength and effective dilution rates with variable meteorological conditions (which vary with $\Delta \mathrm{CO}$ ) from changes associated with aerosol processing in the atmosphere (which do not vary with $\Delta \mathrm{CO}$ ) (De Gouw et al., 2005, 2008; Gilardoni et al., 2009; DeCarlo et al., 2010).

\subsubsection{Diurnal cycles of carboxylic acid and alkane group concentrations}

Diurnal profiles of normalized carboxylic acid group concentrations are classified into the "Afternoon High" and the "Noon High" types (Fig. 4). Both types show higher concentrations at local noon (solar maximum) relative to the early morning period, but they differ in whether the concentration peaked at noon or after noon: the "Afternoon High" type days (type A) have peak concentrations in the afternoon and "Noon High" type days (type B) have peak concentrations at noon. For days within each type, nighttime carboxylic acid group concentrations were variable, with concentrations that were sometimes higher and other times lower than the noon and afternoon values. The variability in concentration at night is likely the result of variations in the land-sea breeze circulations, as illustrated in Fig. B1. Winds coming from the northwest dominate during daytime, and easterlies dominate at night. The variability in nighttime concentrations within each type likely resulted from different air masses brought by the nighttime easterlies. In contrast, there was no evidence for impacts on daytime concentrations from variable sea breezes during the day, consistent with the nearly constant northerly winds shown in Fig. B1 for all days selected for this study. For this reason, our analysis has focused only on the daytime measurements, when the constant wind direction provided a consistent source and nearly constant transport times for emissions from the ports of Los Angeles and Long Beach. This consistency of back trajectories also made the time series measurements effectively pseudoLagrangian. The resulting daytime alkane group profiles (for the same samples as in Fig. 4) resemble and correlate in time with carboxylic acid group concentrations (Fig. 4), indicating alkane and carboxylic acid groups were likely part of the same molecules, forming and condensing at the same time.
The daytime variations of carboxylic acid group concentrations track the $\mathrm{O}_{3}$ mixing ratios (Fig. 4), suggesting that the maximum in acid formation results from $\mathrm{O}_{3}$-driven oxidation (rather than $\mathrm{OH}-$ driven). A correlation of carboxylic acid groups with odd oxygen $\left(\mathrm{O}_{3}+\mathrm{NO}_{2}\right)$ may be stronger than $\mathrm{O}_{3}$ alone (Herndon et al., 2008), but the $\mathrm{NO}_{2}$ measurements were not available in this study. The atmospheric $\mathrm{O}_{3}$ mixing ratio is affected by a number of parameters, including meteorological variables such as solar intensity, temperature, and RH and gas-phase chemical compositions such as $\mathrm{NO}_{\mathrm{x}}$, VOCs, and other factors (Kleinman et al., 1994; Liu et al., 1994; Talbot et al., 2005). There was no consistent difference in the variations and magnitudes of meteorological conditions, including temperature, ambient $\mathrm{RH}$, wind direction and speed, and photosynthetically active radiation between the "Afternoon High" and "Noon High" days, suggesting that the peak time of $\mathrm{O}_{3}$ mixing ratio was likely affected by other parameters, such as $\mathrm{NO}_{\mathrm{x}}$ and VOC mixing ratios (which were not measured at the pier site).

\subsubsection{Diurnal cycles of AMS measured components}

Figure 5 shows diurnal profiles of the AMS-measured fragment $m / z, 44$ and the AMS combustion factor divided into the "Afternoon High" and the "Noon High" days. Fragment $\mathrm{m} / \mathrm{z}, 44$, which is $\mathrm{CO}_{2}{ }^{+}$and representative of highly oxygenated organic components, tracked well with the AMS combustion factor. These two components followed similar patterns to the acid and alkane groups, peaking in the afternoon (14:00-18:00 PST) in the "Afternoon High" days and between noon and afternoon (10:00-14:00 PST) in the "Noon High" days. The daytime peaks of $m / z, 44$ and the combustion factor indicate enhanced SOA formation during the day (De Gouw and Jimenez, 2009). Carboxylic acid group concentration correlated well with $m / z 44$ and the AMS combustion factor concentrations for both "Afternoon High" and "Noon High" type days (Fig. 6), with the latter having better correlation coefficients of both carboxylic acid groups to $\mathrm{m} / \mathrm{z} 44$ and to the combustion factor $(r=0.8)$ but similar slopes. The correlation of carboxylic acid groups and $m / z 44$ indicates that for these organic compositions, carboxylic acid groups and $\mathrm{m} / \mathrm{z}, 44$ were likely associated with the same molecules and same formation mechanisms.

The average diurnal pattern of sulfate is nearly the same as that of $m / z$ 44, the AMS combustion factor (Fig. 5), and the carboxylic acid groups. However, there is no correlation of sulfate and carboxylic acid group concentrations $(r=0.1)$ both for all time-resolved samples and for daily averages. The similarity of the diurnal patterns and the poor correlation of sulfate and carboxylic acid groups suggest that $\mathrm{OH}$ radicals contribute to the formation of both components but that the magnitude of the sulfur and combustion emissions that produce the particles are emitted by different sources. The magnitude of the average daily sulfate concentration shows more variability than the OM concentrations. Dominguez 


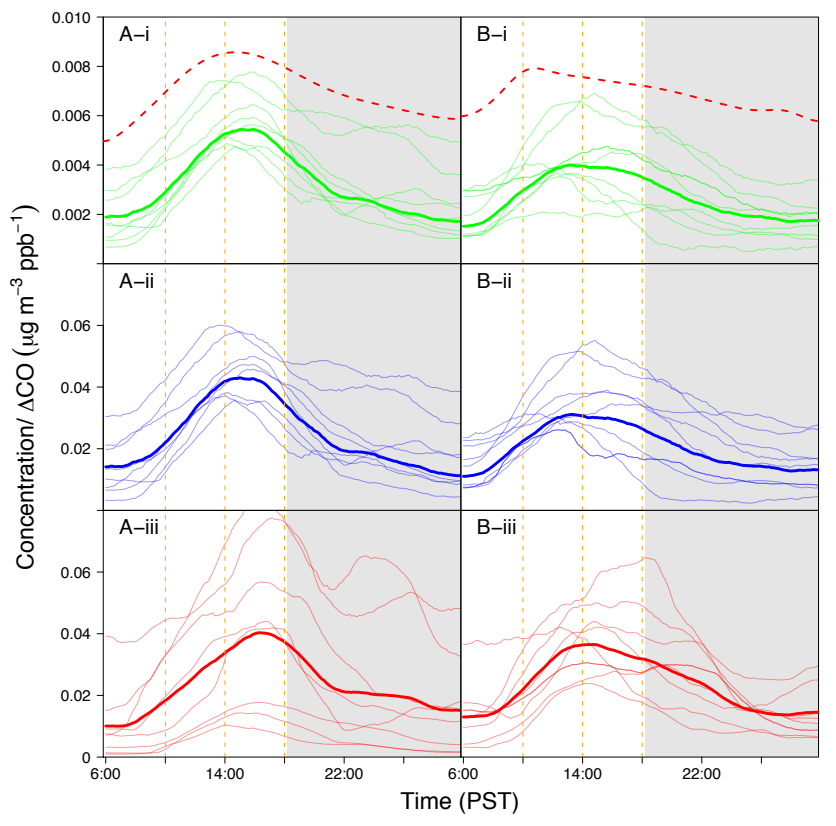

Fig. 5. Diurnal cycles of (i) $m / z$ 44, (ii) the AMS combustion factor, and (iii) sulfate for A ("Afternoon High") and B ("Noon High") days. The thinner lines represent daily diurnal cycles and the thicker lines represent the averages. The red dashed lines are average diurnal profiles of normalized $\mathrm{O}_{3}$ mixing ratios for $\mathbf{A}$ ("Afternoon High") and B ("Noon High") days. The curves (except for $\mathrm{O}_{3}$ ) are smoothed using the "Boxcar Smoothing" method with 30-point averaging to reduce high-frequency noise in the measurements. Shaded areas indicate nighttime periods.

et al. (2008) found that $44 \%$ of the non-sea-salt sulfate in fine particles during a previous study at the same Scripps pier site could be attributed to sulfate from $\mathrm{SO}_{2}$ emitted by ships. However, ship traffic is likely more variable than the OM emissions associated with the urban and port (trucking) activities.

\subsubsection{Diurnal cycles of components in single particles}

To evaluate evidence for photochemical processing in single particles, the average X-ray absorption spectra of single particles are shown in Fig. 7. Twenty-one morning particles and sixteen afternoon particles (collected on the same days as the morning particles) were analyzed. The afternoon-particle spectrum was characterized by a flat and broad black carbon peak at $285 \mathrm{eV}$, a broad peak ranging from 287 to $289 \mathrm{eV}$ (peaks at $288.7 \mathrm{eV}$ ) indicative of alkane (the shoulder at $287.7 \mathrm{eV}$ ) and carboxylic acid $(288.7 \mathrm{eV}$ ) functional group absorption, a carbonate peak at $290.4 \mathrm{eV}$, and two potassium peaks at 297.4 and $299.9 \mathrm{eV}$ (Russell et al., 2002). These spectra are comparable to the spectrum of $\mathrm{CaCO}_{3}$ (Hawkins and Russell, 2010b) except for the carboxylic acid group absorption, suggesting that some carboxylic acid groups may condense on marine particles

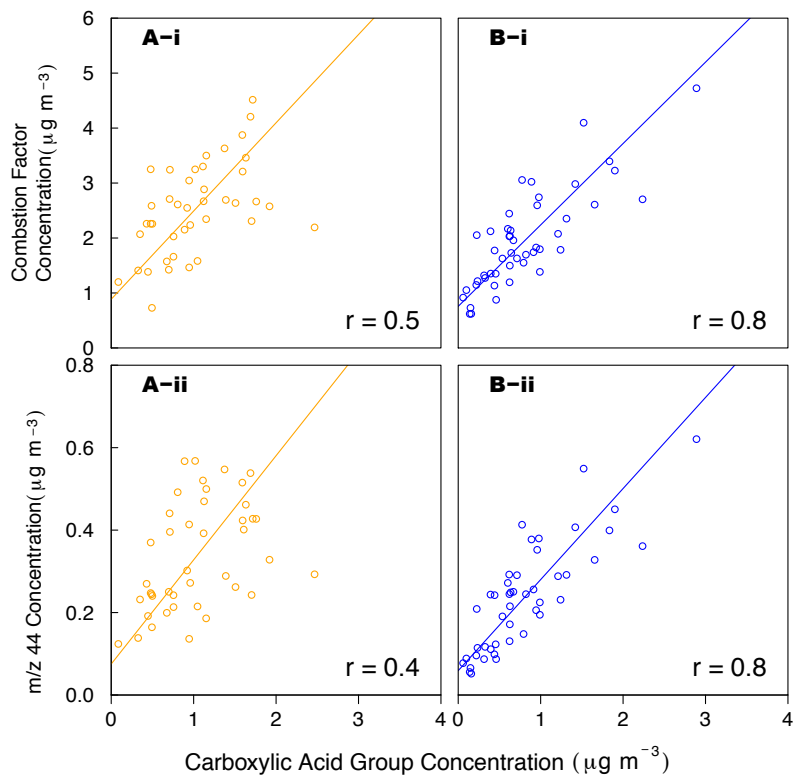

Fig. 6. Mass concentration correlation of carboxylic acid groups with (i) the AMS combustion factor and (ii) $m / z, 44$ for A ("Afternoon High") and B ("Noon High") days. The correlation coefficients are shown in the legends.

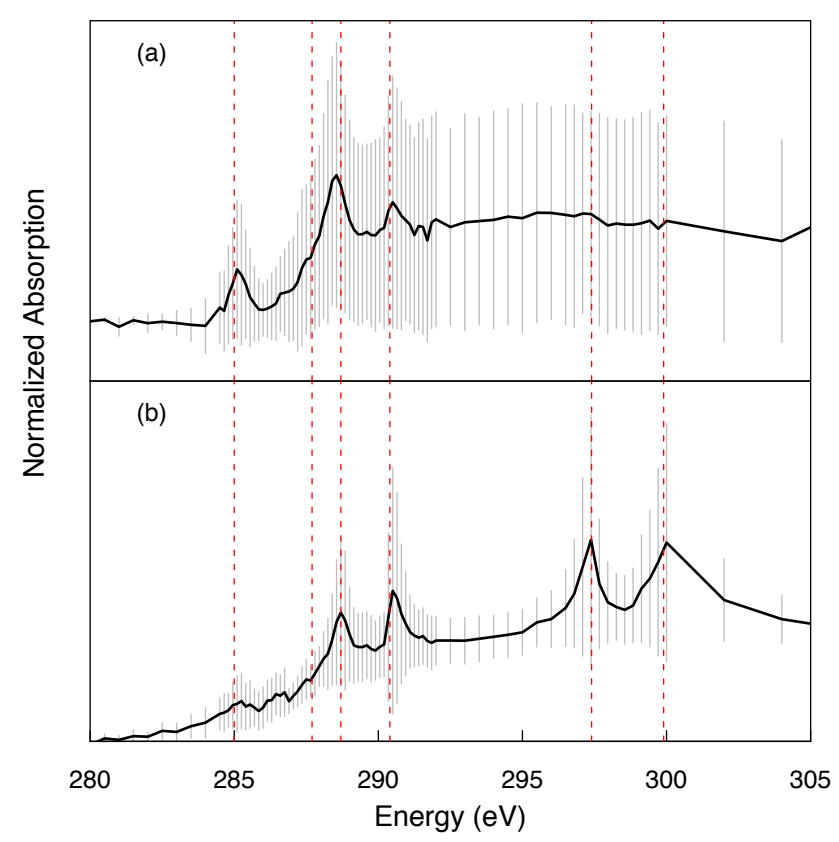

Fig. 7. Average X-ray spectra of (a) twenty-one morning and (b) sixteen afternoon particles. Grey vertical bars indicate the standard deviations of absorption at corresponding energies. Red vertical lines indicate alkene group ( $285 \mathrm{eV})$, alkane group $(287.7 \mathrm{eV})$, carboxylic acid group $(288.7 \mathrm{eV})$, carbonate $(290.4 \mathrm{eV})$, and K (297.4 and $299.9 \mathrm{eV}$ ) absorptions. 
originating from marine calcareous phytoplankton (Hawkins and Russell, 2010b) when air masses passed over the ocean. Compared to the afternoon spectrum, the morning spectrum had a narrower and sharper black carbon peak with more variations at all energies. The graphite content of particles is represented by calculating the $\% \mathrm{sp}^{2}$ hybridization for each particle (Takahama et al., 2007). Morning particles were associated with greater $\% \mathrm{sp}^{2}$ hybridization than afternoon particles at a $84 \%$ confidence level, indicating morning particles were more influenced by primary emissions that likely included black carbon cores.

\section{Discussion}

In this section, we identify the fraction of the measured organic mass that is secondary. We start with the approach that is implicit in a number of recent studies (summarized in Table 4), namely that oxygen-containing organic components that are from fossil fuel combustion emissions, and the other (non-oxygen-containing) organic components that cooccur with them, are secondary. Special attention is given to carboxylic acid functional groups, as they are the canonical low-volatility products of photochemical oxidation of hydrocarbons (Haagen-Smit, 1952). Next, we use the assumption of a Lagrangian evolution of the air mass and the availability of daytime sunlight to separate the OM that is produced in a single day of photochemical reactions. Accounting for the expected multi-day lifetime of SOA, we then compare the two different approaches to quantifying SOA. Finally, we note that marine and terrestrial primary biogenic oxygencontaining organic components need to be excluded from both of these estimates, which is possible using PMF separation and tracers for marine production.

\subsection{SOA identification by chemical composition: contributions of acid groups and oxygenated organic fragments}

Several studies of tropospheric carboxylic acids (Table 4) proposed that carboxylic acids are formed in the atmosphere, based on observed correlations of carboxylic acids to solar radiation or ozone mixing ratio. These methods of SOA identification are supported by model predictions and smog chamber studies that predicted or measured the formation of carboxylic acids (Madronich et al., 1990; Grosjean et al., 1992; Yu et al., 1999). Although direct emission of carboxylic acids (molecules) was also associated with vehicular exhaust (Kawamura and Kaplan, 1987) and meat cooking (Rogge et al., 1991), the lack of correlation of carboxylic acids with tracers from these emissions suggests that the contributions from these primary sources are minor. In addition to carboxylic acid groups, other oxygenated groups (e.g. hydroxyl groups and non-acid carbonyl groups) were identified in smog chamber studies (Kleindienst et al., 2004; Sax et al.,
2005; Lim and Ziemann, 2005). The common conclusion in these studies is that for most urban sources, the oxygenated fraction of $\mathrm{OM}$ is secondary. Using this assumption (that highly oxygenated OM is SOA), these recent studies in a variety of urban and rural regions have found that $50-100 \%$ of the OM measured was SOA (Table 4).

Similarly, if we take this approach to identifying SOA in the Scripps Pier measurements (which were dominated by urban emissions from Los Angeles), we find that the fossil fuel combustion factor is likely secondary, given its high fraction of carboxylic acid groups and associated high O/C. This result gives an average "Total SOA" for this study of $60 \%$ of the OM, well within the range of these other measurements. Since we have specifically separated out the $40 \%$ of OM from non-urban sources (biomass burning and marine $\mathrm{OM}$ ), it is not surprising that we are at the low end of the 50 to $100 \%$ range given in Table 4 (since the studies that reported higher SOA fractions had low non-urban contributions to OM). Furthermore, we can look specifically at what fraction of the SOA is actually acid groups: the "Total SOA" estimated from carboxylic acid groups was $34 \%$ of OM, namely half of the SOA (by mass) is carboxylic acid groups.

\subsection{SOA identification by pseudo-Lagrangian observations: daytime formation of carboxylic acid groups and oxygenated organic fragments}

An alternative way to estimate SOA mass fraction is to assess the amount of additional OM formed during the sunny part of a single day. This approach requires measurements in a pseudo-Lagrangian framework, where we can infer that the photochemical exposure (aging) of the emissions tracks with the time of day. In this case, the majority of the volatile organic compounds (VOCs), in particular those from fossil fuel combustion, was emitted in the Los Angeles - Long Beach region. Further, the transit from that emission point to the Scripps Pier was largely over clean marine regions with small OM sources (as in Hawkins and Russell, 2010a). The other aspect of this study region is that northwesterly flow predominated in daytime, thus also providing sufficient regional homogeneity on the selected days, as illustrated by the day-to-day similarities in Figs. 4 and 5.

With this pseudo-Lagrangian approach, we can identify SOA more specifically using the dependence on sunlight and oxidants during a single day, separating SOA into "Background SOA" (formed on prior days) and "Today's SOA" (formed during a 12-h daytime period of one particular day). In this calculation, "Today's SOA" contributions from carboxylic acid groups and the combustion factors are both estimated by assuming that the minimum concentration that occurs in the early morning is representative of a background value (the "Background SOA" from formation on previous days) and that the increase that occurs (relative to $\Delta \mathrm{CO}$ ) is from photochemical processing during one specific 12 -h 
Table 3. Mass concentration and OM fraction of "Total SOA" (estimated from the "chemical-composition" based method) and "Today's SOA" (estimated from the "pseudo-Lagrangian" based method) calculated from carboxylic acid groups, the FTIR combustion factor, and the AMS combustion factor for the "Afternoon High" and the "Noon High" days.

\begin{tabular}{|c|c|c|c|c|}
\hline \multicolumn{5}{|l|}{ "Afternoon High" Days } \\
\hline & \multicolumn{2}{|c|}{ Concentration $\left(\mu \mathrm{g} \mathrm{m}^{-3}\right)$} & \multicolumn{2}{|c|}{ Fraction of total OM } \\
\hline & Total SOA & Today's SOA & Total SOA & Today's SOA \\
\hline Carboxylic Acid Group & 1.2 & 0.3 & $36 \%$ & $9 \%$ \\
\hline FTIR Combustion Factor & 2.9 & 1.0 & $60 \%$ & $20 \%$ \\
\hline AMS Combustion Factor & 2.5 & 1.1 & $61 \%$ & $27 \%$ \\
\hline \multicolumn{5}{|l|}{ "Noon High" Days } \\
\hline & \multicolumn{2}{|c|}{ Concentration $\left(\mu \mathrm{g} \mathrm{m}^{-3}\right)$} & \multicolumn{2}{|c|}{ Fraction of total OM } \\
\hline & Total SOA & Today's SOA & Total SOA & Today's SOA \\
\hline Carboxylic Acid Group & 1.0 & 0.3 & $30 \%$ & $10 \%$ \\
\hline FTIR Combustion Factor & 3.0 & 0.7 & $62 \%$ & $14 \%$ \\
\hline AMS Combustion Factor & 2.1 & 0.8 & $51 \%$ & $19 \%$ \\
\hline
\end{tabular}

Table 4. Comparison of SOA mass fractions in this study with previous studies. Quantities include (1) OM fraction (PM fraction if specified) of "Total SOA", (2) OM fraction of "Recent SOA" (SOA formed within 1 day or 2 days), (3) OM fraction of "Background SOA", (4) OM fraction (PM fraction if specified) of carboxylic acid (groups), and (5) fraction of "Recent SOA" in "Total SOA".

\begin{tabular}{|c|c|c|c|c|c|c|}
\hline Reference & Total SOA & Recent SOA & $\begin{array}{l}\text { Background } \\
\text { SOA }\end{array}$ & $\begin{array}{l}\text { Carboxylic } \\
\text { Acid (Groups) }\end{array}$ & $\begin{array}{l}\text { Fraction of } \\
\text { Recent SOA } \\
\text { in Total SOA }\end{array}$ & Method of Identification of SOA \\
\hline Schuetzle et al. (1975) ${ }^{1,2}$ & $4 \%$ & - & - & $3 \%$ & - & correlation of acids with solar radiation \\
\hline Cronn et al. (1977) $)^{1,2}$ & $9 \%$ & - & - & $6 \%$ & - & correlation of acids with solar radiation \\
\hline Satsumabayashi et al. (1989) & - & - & - & - & - & correlation of acids with ozone \\
\hline Satsumabayashi et al. (1990) 1,3 & $30-50 \%$ & $22-42 \%$ & $58-78 \%$ & $30-50 \%$ & $72-84 \%$ & correlation of acids with ozone \\
\hline Kawamura and Ikushima (1993) ${ }^{1,2}$ & - & - & - & $0-1 \%$ & - & correlation of acids with ozone \\
\hline Rogge et al. (1993) ${ }^{1}$ & - & - & - & $15-19 \%$ & - & correlation of acids with solar radiation \\
\hline Kawamura and Yasui $(2005)^{1,2}$ & - & - & - & $0-1 \%$ & - & correlation of acids with solar radiation \\
\hline Gilardoni et al. (2007) & $50 \%$ & - & - & $31 \%$ & - & high $\mathrm{O} / \mathrm{C}$ component \\
\hline Lanz et al. (2007) & $60-69 \%$ & - & - & - & - & high $\mathrm{O} / \mathrm{C}$ component \\
\hline Zhang et al. (2007b) & $64-95 \%$ & - & - & - & - & high $\mathrm{O} / \mathrm{C}$ component \\
\hline Russell et al. (2009a) & $70 \%$ & - & - & $31 \%$ & - & high $\mathrm{O} / \mathrm{C}$ component \\
\hline Hildebrandt et al. (2010) & nearly $100 \%$ & - & - & - & - & high $\mathrm{O} / \mathrm{C}$ component \\
\hline Liggio et al. (2010) & $75-95 \%$ & $40-50 \%$ & $35-45 \%$ & - & $42-71 \%$ & high $\mathrm{O} / \mathrm{C}$ component and phothchemcial age \\
\hline This study & $60 \%$ & $15-30 \%$ & $30-45 \%$ & $34 \%$ & $25-50 \%$ & $\begin{array}{l}\text { high } \mathrm{O} / \mathrm{C} \text { component and correlation of acid } \\
\text { groups with ozone }\end{array}$ \\
\hline
\end{tabular}

1 The mass fractions are calculated using a limited number of measured species.

2 The numbers indicate PM fractions.

3 The SOA in this study is assumed to be composed of carboxylic acids only.

daytime (Fig. 8). Since only the combustion factor is accounted for in this calculation, this method estimates only the portion of "Today's SOA" from fossil fuel combustion.

To evaluate the time scale of carboxylic acid group formation, we evaluate the lag time between the peak concentrations in $\mathrm{O}_{3}$ and either $m / z 44$ or the AMS combustion factor. The peak concentrations of $m / z 44$ and the AMS combustion factor occurred approximately $1-2 \mathrm{~h}$ later than the $\mathrm{O}_{3}$ peak for both the "Afternoon High" and the "Noon High" type days (Fig. 5), suggesting that the time scale for the formation of $m / z 44$ and the AMS combustion factor is $1-2 \mathrm{~h}$. The good correlations of carboxylic acid groups to $m / z 44$ and the AMS combustion factor throughout this study allow us to infer that carboxylic acid group formation also had a time scale of 1-2 $\mathrm{h}$ (although a direct observation of the lag is not possible, given the 4-h duration of the FTIR daytime samples, as shown in Fig. 4). 


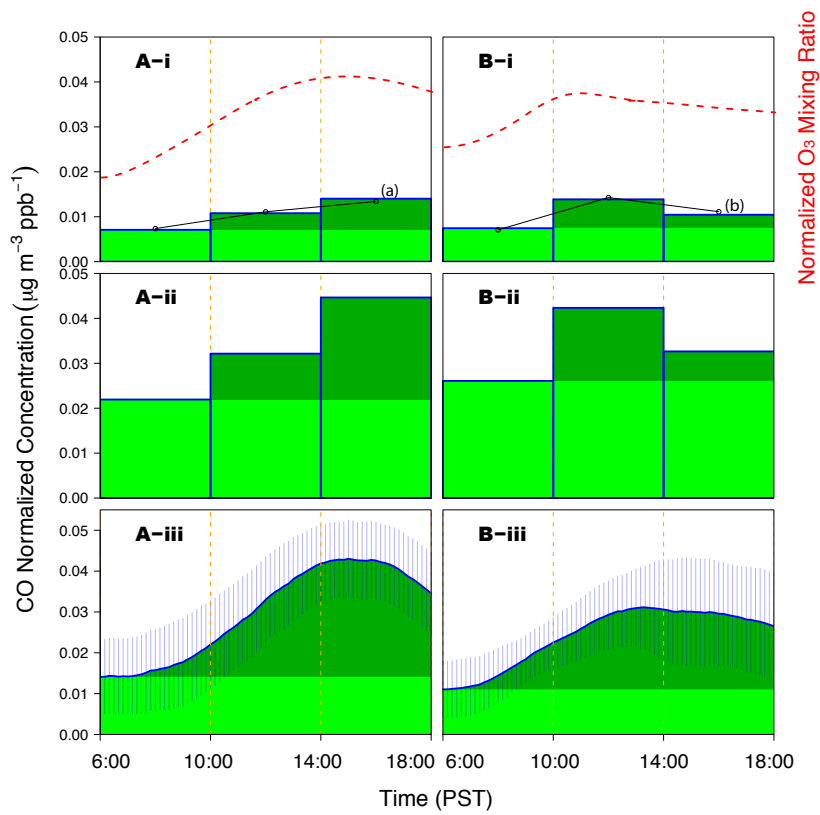

Fig. 8. Daytime profiles of A ("Afternoon High" days) and B ("Noon High" days) for (i) carboxylic acid groups, (ii) the FTIR combustion factor, and (iii) the AMS combustion factor concentration. Colors indicate "Background SOA" (light green) and "Today's SOA" (dark green), respectively. Red dashed lines in panels A-i and $\mathbf{B}$-i represent average daytime profiles of normalized $\mathrm{O}_{3}$. Black lines in panels $\mathbf{A}-\mathbf{i}$ and $\mathbf{B}-\mathbf{i}$ are the average diurnal carboxylic acid group profiles corresponding to the two panels shown in Fig. 4 as indicated by the labels beside the lines. Vertical blue bars in panels A-iii and B-iii show standard deviations of the averaged diurnal cycles.

\subsection{SOA identification by size dependence: surface -limited condensation of oxygenated organic fragments}

The size dependence of the organic components provides additional evidence of how the SOA formed. Representative size distributions of $m / z 44$ and the AMS nrOM are shown in Fig. 9 for the "Afternoon High" days (for time period of 14:00-18:00 PST) and the "Noon High" days (for time period of 10:00-14:00 PST). For both cases, $\mathrm{m} / \mathrm{z} 44$ and nrOM showed similar size distributions with peaks at $300-500 \mathrm{~nm}$, indicating the two components were internally mixed in the particle phase, consistent with the results of the FTIR PMF which associated acid and alkane groups in the combustion factor. The $m / z, 44$ fraction of OM was nearly independent of particle size, while nrOM/PM $\mathrm{PMS}_{\mathrm{Am}}$ decreased with increasing particle diameter, consistent with theoretical models in which acid and alkane groups are added proportionally so give a constant ratio with size (Fig. 9iii), and the total amount of OM increases relative to the particle mass giving a dependence on the reciprocal of the diameter (Fig. 9iv). This result differs slightly from the model presented by Maria et

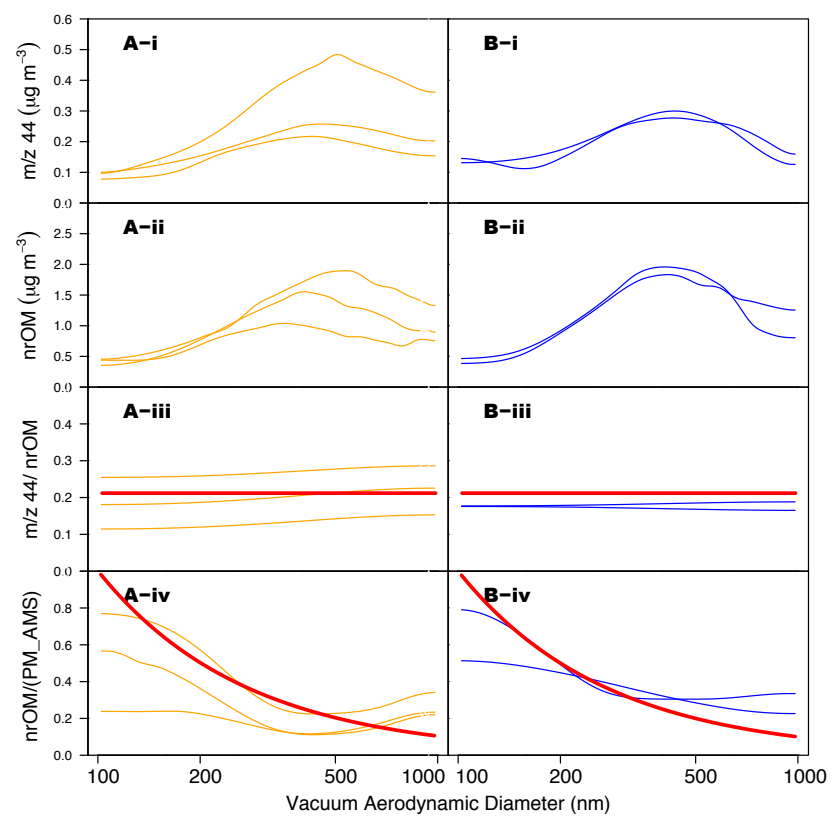

Fig. 9. Representative size distributions for A ("Afternoon High" days) on 12, 16, and 21 September, in time period 14:00-18:00 PST and B ("Noon High" days) on 17 and 20 September in time period 10:00-14:00 PST for (i) $\mathrm{m} / z$ 44, (ii) nrOM, (iii) $(\mathrm{m} / \mathrm{z} 44) / \mathrm{nrOM}$, and (iv) $\mathrm{nrOM} / \mathrm{PM}_{\mathrm{AMS}}$. The ratios $\left((\mathrm{m} / \mathrm{z}, 44) / \mathrm{nrOM}\right.$ and $\left.\mathrm{nrOM} / \mathrm{PM}_{\mathrm{AMS}}\right)$ were calculated for each size bin then plotted versus particle size. The curves are smoothed with the "Boxcar Smoothing" method with 20-point averaging and wavelet de-noising method to reduce high-frequency noise in the measurements. Red lines are theoretical models representing (iii) constant with respect to particle diameter and (iv) inversely proportional to the particle diameter (1/Dp), for comparison to results of Maria et al. (2004).

al. (2004), in which the proportionality of added acid and alkane groups is masked by pre-existing distributions of POA carbon. In this study, the degree and consistency of oxygenation of the fossil fuel combustion fraction (noted in Sect. 4.1) indicates that there was likely no significant mass fraction of preexisting POA.

Single particle analysis using STXM-NEXAFS provides additional information on the size dependence of SOA formation, including specific identification of carboxylic acid groups. The resulting size dependence of OM/PM decreases with increasing size, similar to Fig. 9iv, but the small number of particles analyzed (37) is insufficient to justify more than a linear fit (with $r=-0.6$ ). Interestingly, the size dependence of the acid group fraction of OM increased with increasing size, indicating a possible difference from the $(\mathrm{m} / \mathrm{z}, 44) / \mathrm{OM}$ results (such as non-acid contributions to $m / z 44$ ). However, the variability in the acid fraction for the five different sampling days that were included in these 37 analyzed particles was greater than the dependence on size, suggesting that the aggregation of five samples (each 15-30 min duration) may not be appropriate. Since we also did not have sufficient 
AMS signal to obtain a size distribution in $30 \mathrm{~min}$ of sampling, it is not possible to rule out other factors.

\subsection{Comparing SOA identification methods}

The three SOA identification methods were employed independently using three independent types of OM measurements (FTIR, AMS, STXM-NEXAFS) to characterize SOA, so it is worth assessing the extent to which the resulting characterizations are consistent. The "chemical composition" method was used to quantify the SOA mass and fraction based on the oxygenated nature of the organic associated with fossil fuel combustion tracers (summarized in Table 4). The pseudo-Lagrangian method was used to identify the daytime formation of "Today's SOA" (Table 3 and 4). The "size-dependence" method was used to identify how SOA was formed in the particle phase.

Comparing the two quantitative approaches to SOA, we find from the "chemical composition" method that $60 \%$ of OM is SOA. From the "pseudo-Lagrangian" method, we find that $15-30 \%$ of OM is "Today's SOA." Combining these two results, we find that $25-50 \%$ of SOA is formed each day (on average). This finding is consistent with the expected boundary layer lifetime of particles of 4-5 days, suggesting that the submicron SOA remains on average 4 days (less for the upper bound value of $50 \%$, more after accounting for losses).

There are two previous studies that have separated recent SOA from background SOA (Table 4). The "Background SOA" fraction used here is analogous to the "Background OA" estimated by Liggio et al. (2010) from measurements at Egbert, Ontario (Table 4), except that rather than looking only at "Today's SOA" Liggio et al. (2010) evaluated the SOA formed within $24-48 \mathrm{~h}$. Their estimate for that central Canadian region was $42-71 \%$ of the "Total SOA" (40-50\% of the total OM), which overlaps the range of the "Today's SOA" fraction of $25-50 \%$ of the "Total SOA" (15-30\% of the total $\mathrm{OM}$ ) estimated from the combustion factors found for the coastal region in this study. The median value of the Liggio et al. (2010) range of $56 \%$ is about $50 \%$ larger than the median value of the "Today's SOA" range of $38 \%$ found here, which is consistent with the fact that their time period for "recent" formation was twice as long (and that different sites have different mixtures of sources), the estimates are well within the expected consistency.

We can also look specifically at the acid fraction formed today, which here was found to be $25-33 \%$ of the total acid group concentration. Satsumabayashi et al. (1990) found that in central Japan "Today's acid (molecule)" fraction was $72-84 \%$ of the "Total acids (molecules)." However, the pseudo-Lagrangian approach used in Satsumabayashi et al. (1990) was limited to measurements of only two commonly-observed acids, i.e. succinic acid and phthalic acid, and their emissions in central Japan are quite high.

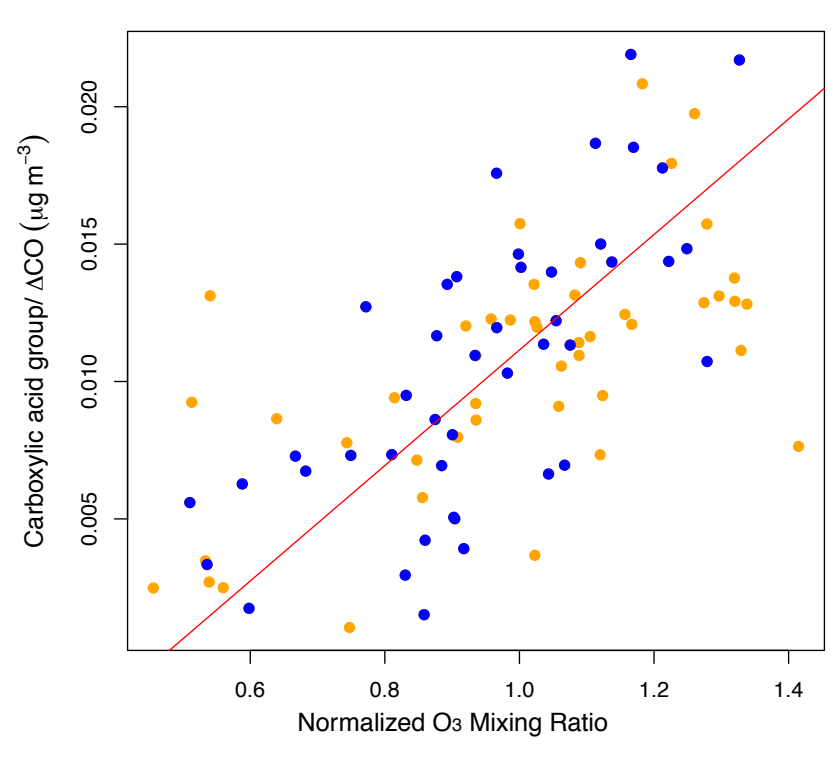

Fig. 10. Correlation of normalized carboxylic acid group concentration and normalized $\mathrm{O}_{3}$ mixing ratio (by campaign average) for the "Afternoon High" (orange) and "Noon High" (blue) days. The correlation coefficient is 0.7 .

Taking the results of all three approaches together, the covariation of daytime concentrations and the correlation of overall concentrations $(r=0.7)$ of carboxylic acid groups and $\mathrm{O}_{3}$ (Figs. 4 and 10) provide substantial evidence for an $\mathrm{O}_{3}-$ driven oxidation that forms carboxylic acid groups. The carboxylic acid, hydroxyl, non-acid carbonyl, and alkane group mole fractions of the combustion factor were $0.11,0.04$, 0.00 , and 0.85 , comparable to the $\mathrm{C}_{12}$ alkane (molecule) oxidation products with mole fractions of $0.12,0.13,0.02$, and 0.73 estimated by Russell et al. (2011). In the mechanism proposed by Russell et al. (2011), gas-phase alkanes (molecules) are oxidized by $\mathrm{OH}$ radicals to form dihydrofuran in the particle phase by $\mathrm{H}$-atom subtraction, isomerization, cyclization, and dehydration processes. Dihydrofuran then evaporates into the gas phase and reacts primarily with $\mathrm{O}_{3}$ to form acid groups - since there is little evidence for carboxylic acid formation from $\mathrm{OH}$ oxidation (Russell et al., 2011; Martin et al., 2002), producing products that are expected to be similar to cyclic alkene oxidation products, namely multi-functional products with carboxylic acid functional groups (which would be expected to partition into the particle phase due to their low vapor pressures). This mechanism is consistent with the observed SOA composition (for the combustion factor) in this study and the co-variation of carboxylic acid and alkane groups. Combining this information with the size dependence of oxygenated mass fragments $(\mathrm{m} / \mathrm{z}, 44)$ supports the hypothesis that these two functional groups were likely formed in the same molecules in the gas phase and condensed simultaneously on particles as secondgeneration products of gas-phase alkane (molecule) oxidation. 


\subsection{Sources and characteristics of hydroxyl functional groups}

Hydroxyl functional groups were mainly from marine sources, since their variation was uncorrelated with the AMS and FTIR combustion factors. Larger contributions from the hydroxyl groups and hence the marine factor were associated with onshore winds from 07:00 to 22:00 PST compared to the offshore-wind concentrations at night), which could bring concentrated marine aerosols to the sampling site, indicating the hydroxyl functional group concentration was modulated by the land-sea breeze circulation at the coastal site. This land-sea breeze effect was not observed for the fossil fuel combustion factors, which dominated the OM. The marine factor concentration weakly correlated with local wind speed ( $r=0.3$ during onshore winds), consistent with the expected increase in particle production from wind-related bubble bursting on the ocean surface (Russell et al., 2010) but sufficiently influenced by other variables to mask a one-toone link. This marine-derived origin of hydroxyl groups indicates that hydroxyl groups are likely dominated by primary emission, especially at coastal regions. This primary contribution was excluded in the SOA mass estimation.

\section{Conclusions}

Measurements at the Scripps Pier show that OM accounted for nearly $50 \%$ of ambient submicron particle mass. The OM was dominated by a fossil fuel combustion factor with a high oxygen-to-carbon ratio. This factor likely represented SOA products formed from fossil fuel emissions from Los Angeles and Long Beach regions, suggesting the "Total SOA" accounted for $60 \%$ of the total OM, with $42 \%$ from acid groups and $51 \%$ from alkane groups. Based on the recurrence of diurnal cycles of the combustion factor and carboxylic acid groups, the "Total SOA" was further separated into "Today's SOA" (formed in the 12-h daytime of a single day) and "Background SOA" (formed on prior days) using a pseudo-Lagrangian approach. In this calculation, the fraction of the combustion factor OM that formed as "Today's SOA" accounted for $25-50 \%$ of the "Total SOA" and $15-30 \%$ of the total OM, while the "Background SOA" contributed to $30-45 \%$ of the total OM, which likely represented the SOA formed in the previous 1-3 days. Similarly, carboxylic acid groups formed as "Today's SOA" accounted for $25-33 \%$ of the total carboxylic acid groups and $10 \%$ of the OM. The SOA was likely formed through surface-limited condensation processes, as suggested by the size dependence of $\mathrm{nrOM} / \mathrm{PM}_{\mathrm{AMS}}$ (decrease with an increase in particle size). In addition, the independence of $(\mathrm{m} / \mathrm{z}, 44) / \mathrm{nrOM}$ on particle size suggests that particle-phase $m / z, 44$ (and likely carboxylic acid groups) and other organic components (largely alkane groups) were formed and condensed simultaneously.
The daytime increase of carboxylic acid groups and the combustion factor mass concentration closely correlated with the $\mathrm{O}_{3}$ mixing ratio, indicating the SOA formation was likely driven by $\mathrm{O}_{3}$. Moreover, the composition of the SOA (the combustion factor) was consistent with the $\mathrm{O}_{3}$-driven gasphase alkane (molecule) oxidation mechanism proposed by Russell et al. (2011), suggesting carboxylic acid and alkane groups are second-generation products (of gas-phase alkane (molecule) oxidation) formed in the same molecules, consistent with the observed co-variation of these two functional groups in the particle phase size distribution. This large contribution of gas-phase alkane (molecule)-derived SOA is not surprising given their large contributions to $\mathrm{VOC}$ emissions in the Los Angeles-Long Beach source region and the relative absence of significant additional organic precursors during transit in the coastal marine boundary layer. This study indicates the importance of gas-phase alkane (molecule) photochemistry for the air quality of regions downwind of large emission sources.

\section{Appendix A}

\section{PMF analysis of the FTIR and the AMS measurements}

\section{A1 PMF of the FTIR spectra}

PMF was applied to the 234 mass-weighted and baselined FTIR spectra. The scaling factors were estimated by baselining errors calculated using the automated algorithm described by Russell et al. (2009a). The robust mode was used and the outliers were downweighted during the fitting procedure. Two to six factors with an FPEAK range of $(0, \pm 0.2$, $\pm 0.4, \pm 0.6, \pm 0.8, \pm 1$ ) were tested. Plotting Q (the sum of squared scaled residuals) versus FPEAK showed that the lowest $\mathrm{Q}$ values corresponded to FPEAK of $-0.2,0$, and 0.2 , which resulted in the same factors. The edge-FPEAK values $( \pm 0.6, \pm 0.4, \pm 0.8$, and \pm 1$)$ resulted in increased $Q$ values, indicating increased residuals associated with the PMF model (Lanz et al., 2007). Because the sensitivity to rotation was negligible for FPEAK $=-0.2,0$, and 0.2 , FPEAK $=0$ was selected to represent the solution.

$Q$ can also be used as a mathematical diagnostic of the PMF solutions. $Q / Q_{\exp }$ (normalized $Q$ ), in which $Q_{\exp }$ approximately represents the degree of freedom of the fitted data, is greater than 4 for the two- and three-factor solutions and smaller than 3 for the $n>3$ solutions (Fig. A2). This decrease of normalized $Q$ indicates that the additional factors in the $n>3$ solutions explain significantly more variation of the data. Therefore, two- and three-factor solutions were excluded.

Factors that correlated $(r>0.5)$ with similar compositions were identified in the four-, five-, and six- factor solutions, indicating some factors that split into indistinguishable and 
(a)

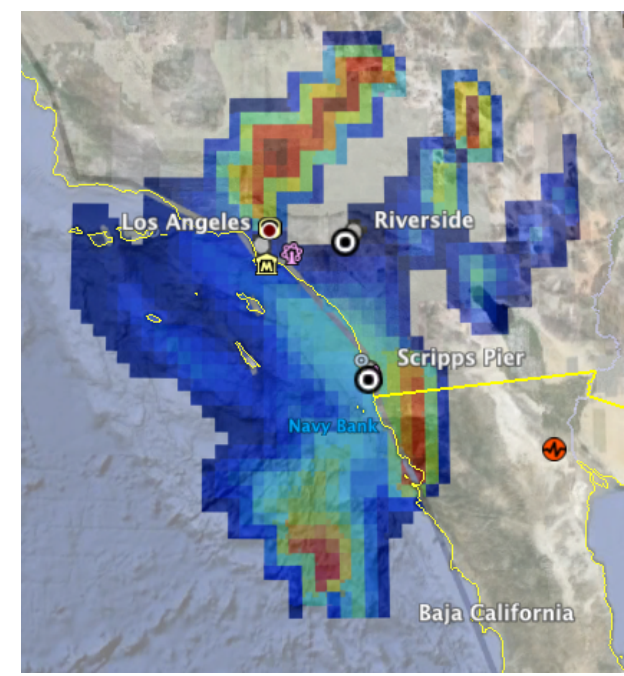

(b)

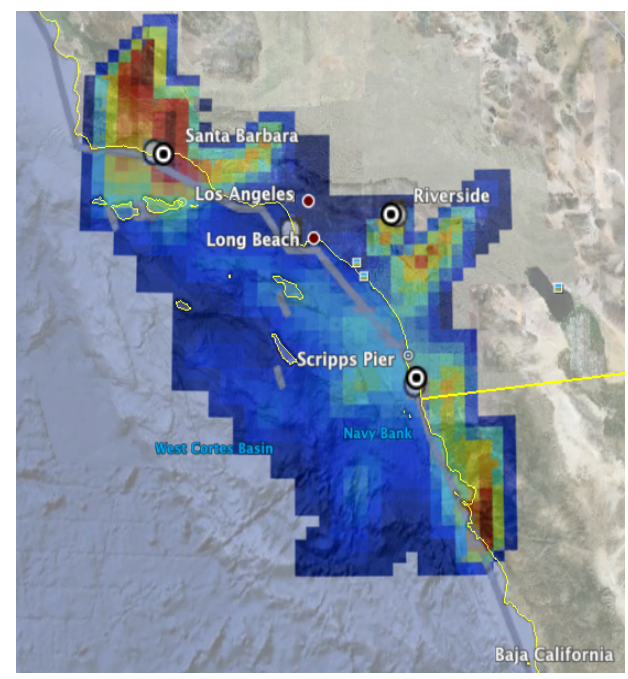

(c)

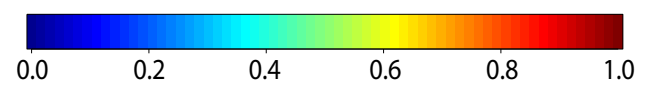

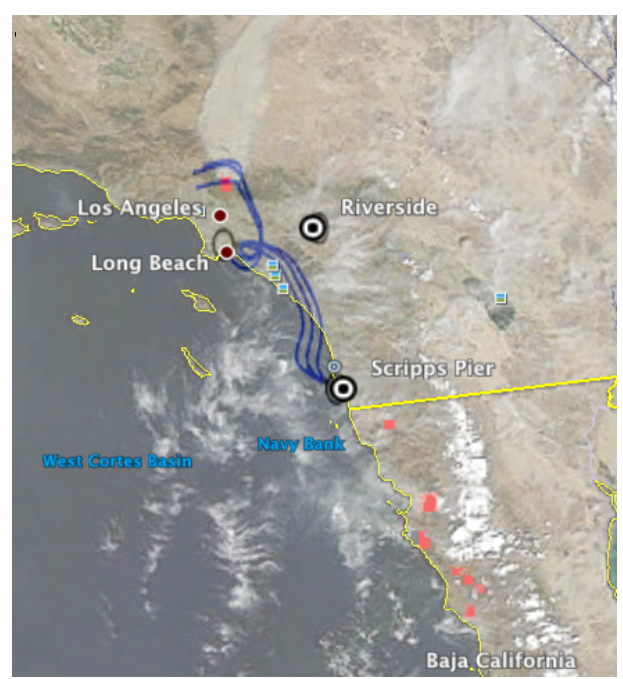

Fig. A1. Potential Source Contribution Function (PSCF) images of (a) the FTIR combustion factor and (b) the FTIR biomass burning factor with warmer colors indicate higher probability. (c) Fire map on 29 August 2009 with red points showing fire spots and blue lines indicating back trajectories ending at the Scripps Pier. The fire image was obtained from NOAA's Aqua satellite.

non-independent components (Ulbrich et al., 2009). The correlated factors in each solution were combined to one factor, resulting in three factors for each of the four-, five-, and six-factor solutions. The combined factors explain the same degree of the OM variability as the individual factors used from the four-, five-, and six-factor solutions, and the combined factor mass is equal to the sum of individual factor masses. The three recombined factors resulting from the six-factor solution were selected because these factors captured events that were associated with trajectories from either known wildfires or from Los Angeles-Long Beach ports. In addition, the factor profiles had similar peak struc- ture $(r>0.8)$ with the known factors derived from the TEXAQS/GoMACCS 2006 and the Scripps Pier 2008 measurements (Hawkins and Russell, 2010a; Russell et al., 2009a).

The factors were identified by comparing factor spectrum and composition with previously identified factors. The first factor spectrum correlated to the fossil fuel combustion factor profiles of the TEXAQS/GoMACCS (Russell et al., 2009a) and the Scripps Pier 2008 measurements (Hawkins and Russell, 2010a) projects with $\mathrm{r}$ of 0.97 and 0.99 , respectively, indicating similar organic compositions from similar sources or processes. This factor was characterized by large fractions and co-existence of alkane and carboxylic 


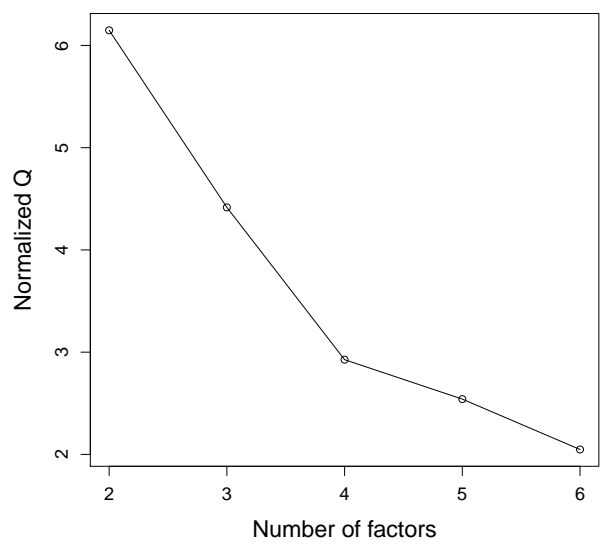

Fig. A2. Normalized $Q$ values versus number of factors for the FTIR PMF analysis.

acid functional groups (51\% and $42 \%$ of the factor OM, respectively) and was identified as a fossil fuel combustion factor. The concentration of this factor was $3.0 \mu \mathrm{g} \mathrm{m}^{-3}$, accounting for $62 \%$ of the $\mathrm{OM}$ on average (Fig. 2c). Hydroxyl and amine functional groups contributed $7 \%$ and $1 \%$ of the factor OM, respectively. The PSCF image (Fig. A1a) shows the origin of this factor was mainly located at the vicinity of the Los Angeles region, which are dominated by fossil fuel combustion emissions. The second factor spectrum correlated to the biomass burning factor profiles identified from the TEXAQS/GoMACCS (Russell et al., 2009a) and the Scripps Pier 2008 measurements (Hawkins and Russell, 2010a) with $r$ of 0.87 and 0.93, respectively. The factor fraction time series (Fig. 2c) showed three high concentration periods: 26 August-2 September, 8-22 August, and 22-27 September, corresponding to the three largest fires (by acreage) that occurred in the Southern California region that summer: the Station fire (in Los Angeles County), the La Brea fire (in Santa Barbara County), and the Guiberson fire (in Ventura County), respectively (http://www.fire.ca.gov/fire_protection/fire_protection fire_info_redbooks_2009.php). The PSCF image (Fig. A1b) indicates that this factor is likely from north of Los Angeles - Santa Barbara County, as well as Baja California regions, consistent with fire events that occurred during the sampling period and fire maps from satellite measurements (Fig. A1c). Based on the similarity of this factor spectrum to previously identified biomass burning factors and the increase in concentration during fire-influenced time periods, this factor was identified as a biomass burning factor. The factor concentration was $0.88 \mu \mathrm{g} \mathrm{m}^{-3}$ on average and accounted for $18 \%$ of the OM. Non-acid carbonyl and alkane functional groups dominated this factor, accounting for $44 \%$ and $34 \%$ of the factor $\mathrm{OM}$, respectively. The factor spectrum of the third factor was comparable $(r=0.82)$ to the spectrum of the polluted marine factor described in the Scripps Pier 2008 measurements (Hawkins and Russell, 2010a). This factor was identified as a marine factor that accounted for $20 \%$ of the $\mathrm{OM}$ on average and was dominated by hydroxyl functional groups $(72 \%)$. Alkane, carboxylic acid, and amine functional groups contributed $20 \%, 4 \%$, and $3 \%$ of the OM, respectively. The concentration and composition of the factors are summarized in Table 2.

\section{A2 PMF of organic fragment concentrations}

PMF was applied to the time series of concentrations of 271 AMS-measured organic mass fragments. The input matrix and the error files for PMF of the AMS measurements were prepared using the Igor Pro 5 (Wavemetrics Inc.) codes based on the work of Zhang et al. (2005). Two to six factors with FPEAK-range of $[0, \pm 0.2, \pm 0.4, \pm 0.6, \pm 0.8, \pm 1]$ were investigated. The $\mathrm{Q}$ versus FPEAK plot shows the lowest $\mathrm{Q}$ values corresponding to FPEAK values of $-0.2,0$, and 0.2 . The factors generated for each rotation were nearly indistinguishable. FPEAK $=0$ was selected to represent the solutions. A distinct factor with significant mass was missing when two factors were used. For each of the four-, five-, and six-factor solutions, highly correlated factors $(r>0.7)$ were combined, resulting in three recombined factors, which resembled the three factors generated from the three-factor solution. The normalized $Q$ values for the three-six factor solutions are comparable (differences are within $10 \%$ ), indicating three factors were enough for explaining the variability of the input data matrix. Therefore, the three-factor solution was selected, which reproduced $98 \%$ of the OM variability.

The factors were identified by comparing normalized factor spectra with the online AMS reference spectra (Ulbrich et al., 2007, 2009). The first factor $\mathrm{m} / \mathrm{z}$ spectrum correlated to several LV-OOA (low-volatility oxygenated organic aerosol) and SOA spectra. For example, the factor spectrum correlated to the Pittsburgh OOA factor spectrum (Zhang et al., 2005; $r=0.93$ for $m / z>44$ and $r=0.95$ for all $\mathrm{m} / z$ ) and the spectrum from the photooxidation of m-xylene with seed aerosols under $\mathrm{RH}=55 \%$ (Bahreini et al., 2005; $r=0.94$ for $\mathrm{m} / z>44$ and $r=0.90$ for all $\mathrm{m} / \mathrm{z}$ ). The factor could not be further split into LV-OOA and SV-OOA (semi-volatile OOA) factors as shown in many previous studies ( $\mathrm{Ng}$ et al., 2010), likely because of the relatively low particle concentration at the sampling site as well as the lower resolution of the quadropole MS. The diurnal cycle of this factor showed a significant increase in concentration during the day and lower values in the morning and at night (Fig. 5), indicating photochemical origins of this factor. This factor likely represented an aged component formed from processed primary emissions. The factor was identified as an aged combustion factor, which accounted for $61 \%$ of the nrOM and was associated with the largest $\mathrm{m} / \mathrm{z}, 44$ fraction (of nrOM) and the largest $\mathrm{m} / \mathrm{z}, 44$ to $\mathrm{m} / \mathrm{z}, 43$ ratio of all of the factors (Table 2). The second factor profile strongly correlated with the wood burning spectrum $(r=0.90$ for both $\mathrm{m} / \mathrm{z}>44$ for all $\mathrm{m} / \mathrm{z}$ ) identified by Lanz et al. (2007) and the brush fire spectrum $(r=0.94$ 


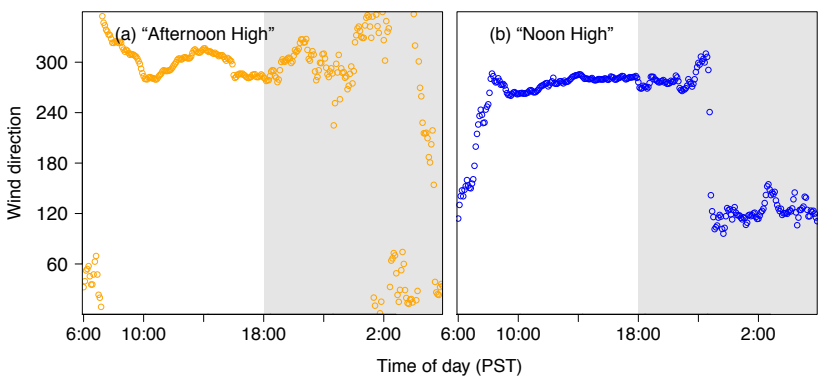

Fig. B1. Vector-averaged diurnal cycles of wind direction (0 degree indicates wind coming from north) divided into (a) "Afternoon High" and (b) "Noon High" types. Shaded areas indicate nighttime periods.

for $m / z>44$ and $r=0.92$ for all $m / z$ ) described by Bahreini et al. (2005). This factor was identified as a biomass burning factor, accounting for $26 \%$ of the nrOM. No correlation was found between the third factor spectrum and the spectra from the AMS database. The factor concentration correlated to none of the concentrations of the AMS-measured inorganic compounds. The factor profile correlated moderately $(r=0.5)$ with the third factor (which was likely influenced by the ocean) from the ICEALOT study (Frossard et al., 2011) and the time series correlated to that of the FTIR marine factor with $r=0.5$. This factor may be a shipping or marine factor, which accounted for $13 \%$ of the nrOM.

\section{Appendix B}

\section{Wind direction effects on chemical concentration}

The daytime wind direction was consistent during the study, with winds coming from northwest dominating during the 32 days selected for sample analysis. At night, easterly winds dominated but were more variable (Fig. 1b). The average diurnal profiles of wind direction for the "Afternoon High" and the "Noon High" days are shown in Fig. B1. Sea breeze effects on the daytime particle concentrations were not identified. Variability in the concentrations of carboxylic acid groups and alkane groups at night likely result from different sources brought by easterly winds at night. For this reason, the nighttime samples were excluded from the diurnal cycle analysis.

Acknowledgements. We acknowledge Ray Weiss for providing CO measurements, with funding from the California Air Resources Board. We also are grateful for support from the University of California, San Diego - Pacific Northwest National Laboratory Aerosol Chemistry Climate Institute and NSF grant ATM-0744636. We also thank Kimberly Prather and Cassandra Gaston for providing $\mathrm{O}_{3}$ measurements during this project.

Edited by: N. M. Donahue

\section{References}

Altieri, K., Carlton, A., Lim, H., Turpin, B., and Seitzinger, S.: Evidence for oligomer formation in clouds: Reactions of isoprene oxidation products, Environ. Sci. Technol., 40, 4956-4960, 2006.

Ault, A., Moore, M., Furutani, H., and Prather, K.: Impact of emissions from the Los Angeles port region on san diego air quality during regional transport events, Environ. Sci. Technol., 43, 3500-3506, 2009.

Bahreini, R., Keywood, M., Ng, N., Varutbangkul, V., Gao, S., Flagan, R., Seinfeld, J., Worsnop, D., and Jimenez, J.: Measurements of secondary organic aerosol from oxidation of cycloalkenes, terpenes, and m-xylene using an Aerodyne aerosol mass spectrometer, Environ. Sci. Technol., 39, 5674-5688, 2005.

Blando, J. and Turpin, B.: Secondary organic aerosol formation in cloud and fog droplets: a literature evaluation of plausibility, Atmos. Environ., 34, 1623-1632, 2000.

Claeys, M., Szmigielski, R., Kourtchev, I., Van der Veken, P., Vermeylen, R., Maenhaut, W., Jaoui, M., Kleindienst, T., Lewandowski, M., Offenberg, J., and Edney, E. O.: Hydroxydicarboxylic acids: Markers for secondary organic aerosol from the photooxidation of $\alpha$-pinene, Environ. Sci. Technol., 41, 16281634, 2007.

Cronn, D. R., Charlson, R. J., Knights, R. L., Crittenden, A. L., and Appel, B. R.: A survey of the molecular nature of primary and secondary components of particles in urban air by high-resolution mass spectrometry, Atmos. Environ., 11, 929937, 1977.

Day, D., Liu, S., Russell, L., and Ziemann, P.: Organonitrate group concentrations in submicron particles with high nitrate and organic fractions in coastal southern California, Atmos. Environ. 44, 1970-1979, 2010.

De Gouw, J. and Jimenez, J.: Organic aerosols in the Earth's atmosphere, Environ. Sci. Technol., 43, 7614-7618, 2009.

De Gouw, J., Middlebrook, A., Warneke, C., Goldan, P., Kuster, W., Roberts, J., Fehsenfeld, F., Worsnop, D., Canagaratna, M., Pszenny, A., Keene, W. C., Marchewka, M., Bertman, S. B., and Bates, T. S.: Budget of organic carbon in a polluted atmosphere: Results from the New England Air Quality Study in 2002, J. Geophys. Res.-Atmos., 110, D16305, doi:10.1029/2004JD005623, 2005.

De Gouw, J., Brock, C., Atlas, E., Bates, T., Fehsenfeld, F., Goldan, P., Holloway, J., Kuster, W., Lerner, B., Matthew, B., Middlebrook, A. M., Onasch, T. B., Peltier, R. E., Quinn, P. K., Senff, C. J., Stohl, A, Sullivan, A. P., Trainer, M., Warneke, C., Weber, R. J., and Williams, E. J.: Sources of particulate matter in the northeastern United States in summer: 1. Direct emissions and secondary formation of organic matter in urban plumes, J. Geophys. Res.-Atmos., 113, D08301, doi:10.1029/2007JD009243, 2008.

DeCarlo, P. F., Dunlea, E. J., Kimmel, J. R., Aiken, A. C., Sueper, D., Crounse, J., Wennberg, P. O., Emmons, L., Shinozuka, Y., Clarke, A., Zhou, J., Tomlinson, J., Collins, D. R., Knapp, D., Weinheimer, A. J., Montzka, D. D., Campos, T., and Jimenez, J. L.: Fast airborne aerosol size and chemistry measurements above Mexico City and Central Mexico during the MILAGRO campaign, Atmos. Chem. Phys., 8, 4027-4048, doi:10.5194/acp8-4027-2008, 2008

DeCarlo, P. F., Ulbrich, I. M., Crounse, J., de Foy, B., Dunlea, 
E. J., Aiken, A. C., Knapp, D., Weinheimer, A. J., Campos, T., Wennberg, P. O., and Jimenez, J. L.: Investigation of the sources and processing of organic aerosol over the Central Mexican Plateau from aircraft measurements during MILAGRO, Atmos. Chem. Phys., 10, 5257-5280, doi:10.5194/acp-10-52572010, 2010.

Dominguez, G., Jackson, T., Brothers, L., Barnett, B., Nguyen, B., and Thiemens, M. H.: Discovery and measurement of an isotopically distinct source of sulfate in Earth's atmosphere, Proc. Natl. Acad. Sci., doi:10.1073/pnas.0805255105, 2008.

Draxler, R. and Rolph, G.: HYSPLIT (HYbrid Single-Particle Lagrangian Integrated Trajectory) Model access via NOAA ARL READY Website: http://www.arl.noaa.gov/ready/hysplit4.html, NOAA Air Resources Laboratory, Silver Spring, 2003.

Edney, E., Kleindienst, T., Jaoui, M., Lewandowski, M., Offenberg, J., Wang, W., and Claeys, M.: Formation of 2-methyl tetrols and 2-methylglyceric acid in secondary organic aerosol from laboratory irradiated isoprene/ $\mathrm{NO}_{\mathrm{x}} / \mathrm{SO}_{2} /$ air mixtures and their detection in ambient $\mathrm{PM}_{2.5}$ samples collected in the eastern United States, Atmos. Environ., 39, 5281-5289, 2005.

Ervens, B., Feingold, G., Frost, G., and Kreidenweis, S.: A modeling study of aqueous production of dicarboxylic acids: 1 . Chemical pathways and speciated organic mass production, J. Geophys. Res.-Atmos., 109, D15205, doi:10.1029/2003JD004387, 2004.

Fisseha, R., Dommen, J., Sax, M., Paulsen, D., Kalberer, M., Maurer, R., H

"ofler, F., Weingartner, E., and Baltensperger, U.: Identification of organic acids in secondary organic aerosol and the corresponding gas phase from chamber experiments, Anal. Chem., 76, 6535-6540, 2004.

Fraser, M., Yue, Z., Tropp, R., Kohl, S., and Chow, J.: Molecular composition of organic fine particulate matter in Houston, TX, Atmos. Environ., 36, 5751-5758, 2002.

Frossard, A. A., Shaw, P. M., Russell1, L. M., Kroll, J. H., Canagartna, M., Worsnop, D., Quinn, P. K., and Bates, T. S.: Springtime Arctic Haze Contributions of Submicron Organic Particles from European and Asian combustion Sources, J. Geophys. Res.Atmos., 116, D05205, , 2011.

Fuzzi, S., Andreae, M. O., Huebert, B. J., Kulmala, M., Bond, T. C., Boy, M., Doherty, S. J., Guenther, A., Kanakidou, M., Kawamura, K., Kerminen, V.-M., Lohmann, U., Russell, L. M., and Pöschl, U.: Critical assessment of the current state of scientific knowledge, terminology, and research needs concerning the role of organic aerosols in the atmosphere, climate, and global change, Atmos. Chem. Phys., 6, 2017-2038, doi:10.5194/acp-62017-2006, 2006.

Ge, X., Wexler, A. S., and Clegg, S. L.: Atmospheric Amines-Part I. A review, Atmos. Environ., 524-546, 2011.

Gilardoni, S., Russell, L. M., Sorooshian, A., Flagan, R. C., Seinfeld, J. H., Bates, T. S., Quinn, P. K., Allan, J. D., Williams, B., Goldstein, A. H., Onasch, T. B., Worsnop, D. R.: Regional variation of organic functional groups in aerosol particles on four US east coast platforms during the International Consortium for Atmospheric Research on Transport and Transformation 2004 campaign, J. Geophys. Res.-Atmos., 112, D10S27, doi:10.1029/2006JD007737, 2007.

Gilardoni, S., Liu, S., Takahama, S., Russell, L. M., Allan, J. D., Steinbrecher, R., Jimenez, J. L., De Carlo, P. F., Dunlea, E. J., and Baumgardner, D.: Characterization of organic ambient aerosol during MIRAGE 2006 on three platforms, Atmos. Chem. Phys., 9, 5417-5432, doi:10.5194/acp-9-5417-2009, 2009.

Gray, H., Cass, G., Huntzicker, J., Heyerdahl, E., and Rau, J.: Characteristics of atmospheric organic and elemental carbon particle concentrations in Los Angeles, Environ. Sci. Technol., 20, 580589, 1986.

Grosjean, D., Van Cauwenberghe, K., Schmid, J., Kelley, P., and Pitts Jr., J.: Identification of C3-C10 aliphatic dicarboxylic acids in airborne particulate matter, Environ. Sci. Technol., 12, 313317, 1978.

Grosjean, D.: In situ organic aerosol formation during a smog episode: estimated production and chemical functionality, Atmospheric Environment. Part A. General Topics, 26, 953-963, 1992.

Haagen-Smit, A. J.: Chemistry and physiology of Los Angeles smog, Ind. Eng. Chem., 17, 1342-1346, 1952.

Hallquist, M., Wenger, J. C., Baltensperger, U., Rudich, Y., Simpson, D., Claeys, M., Dommen, J., Donahue, N. M., George, C., Goldstein, A. H., Hamilton, J. F., Herrmann, H., Hoffmann, T., Iinuma, Y., Jang, M., Jenkin, M. E., Jimenez, J. L., Kiendler-Scharr, A., Maenhaut, W., McFiggans, G., Mentel, Th. F., Monod, A., Prvt, A. S. H., Seinfeld, J. H., Surratt, J. D., Szmigielski, R., and Wildt, J.: The formation, properties and impact of secondary organic aerosol: current and emerging issues, Atmos. Chem. Phys., 9, 5155-5236, doi:10.5194/acp-95155-2009, 2009.

Hawkins, L. N. and Russell, L. M.: Oxidation Of Ketone Groups In Transported biomass burning Aerosol From The 2008 Northern California Lightning Series Fires, Atmos. Environ., 44, 41424154, 2010a.

Hawkins, L. N. and Russell, L. M.: Polysaccharides, Proteins, and Phytoplankton Fragments: Four Chemically Distinct Types of marine Primary Organic Aerosol Classified by Single Particle Spectromicroscopy, Adv. Meteorol., 2010, 612132, doi:10.1155/2010/612132, 2010b.

Herndon, S., Onasch, T., Wood, E., Kroll, J., Canagaratna, M., Jayne, J., Zavala, M., Knighton, W., Mazzoleni, C., Dubey, M., Ulbrich, I. M., Jimenez, J. L., Seila, R., de Gouw J. A., de Foy, B., Fast, J., Molina, L. T., Kolb, C. E., and Worsnop, D. R.: Correlation of secondary organic aerosol with odd oxygen in Mexico City, Geophys. Res. Lett., 35, L15804, doi:10.1029/2008GL034058, 2008.

Hildebrandt, L.,Engelhart, G. J., Mohr, C., Kostenidou, E., Lanz, V. A., Bougiatioti, A., DeCarlo, P. F., Prevot, A. S. H., Baltensperger, U., Mihalopoulos, N., Donahue, N. M., and Pandis, S. N.: Aged organic aerosol in the Eastern Mediterranean: the Finokalia aerosol measurement experiment-2008, Atmos. Chem. Phys, 10, 4167-4186, doi:10.5194/acp-10-4167-2010, 2010.

Hughes, M., Hall, A., and Fovell, R.: Dynamical controls on the diurnal cycle of temperature in complex topography, Clim. Dynam., 29, 277-292, 2007.

Jaoui, M., Kleindienst, T. E., Lewandowski, M., and Edney, E. O.: Identification and quantification of aerosol polar oxygenated compounds bearing carboxylic or hydroxyl groups. 1. Method development, Anal. Chem., 76, 4765-4778, 2004.

Jayne, J., Leard, D., Zhang, X., Davidovits, P., Smith, K., Kolb, C., and Worsnop, D.: Development of an aerosol mass spectrometer for size and composition analysis of submicron particles, Aerosol. Sci. Tech., 33, 49-70, 2000. 
Kawamura, K.: Identification of C2-C10. omega.-oxocarboxylic acids, pyruvic acid, and C2-C3. alpha.-dicarbonyls in wet precipitation and aerosol samples by capillary GC and GC/MS, Anal. Chem., 65, 3505-3511, 1993.

Kawamura, K. and Gagosian, R.: Implications of $\omega$-oxocarboxylic acids in the remote marine atmosphere for photo-oxidation of unsaturated fatty acids, Nature, 325, 330-332, 1987.

Kawamura, K. and Ikushima, K.: Seasonal changes in the distribution of dicarboxylic acids in the urban atmosphere, Environ. Sci. Technol., 27, 2227-2235, 1993.

Kawamura, K. and Yasui, O.: Diurnal changes in the distribution of dicarboxylic acids, ketocarboxylic acids and dicarbonyls in the urban Tokyo atmosphere, Atmos. Environ., 39, 1945-1960, 2005.

Kawamura, K. and Kaplan, I. R.: Motor exhaust emissions as a primary source for dicarboxylic acids in Los Angeles ambient air, Environ. Sci. Technol, 21, 105-110, 1987.

Kilcoyne, A. L. D., Tyliszczak, T., Steele, W. F., Fakra, S., Hitchcock, P., Franck, K., Anderson, E., Harteneck, B., Rightor, E. G., Mitchell, G. E., Hitchcock, A. P., Yang, L., Warwickc, T., and Ade, H.: Interferometer-controlled scanning transmission X-ray microscopes at the Advanced Light Source, J. Synch. Radiat., 10 (2), 125-136, 2003.

Kleindienst, T., Smith, D., Li, W., Edney, E., Driscoll, D., Speer, R., and Weathers, W.: Secondary organic aerosol formation from the oxidation of aromatic hydrocarbons in the presence of dry submicron ammonium sulfate aerosol, Atmos. Environ., 33, 36693681, 1999.

Kleindienst, T. E., Conver, T. S., McIver, C. D., and Edney, E. O.: Determination of secondary organic aerosol products from the photooxidation of toluene and their implications in ambient $\mathrm{PM}_{2.5}$, Environ. Sci. Technol., 47, 79-100, 2004.

Kleindienst, T., Edney, E., Lewandowski, M., Offenberg, J., and Jaoui, M.: Secondary organic carbon and aerosol yields from the irradiations of isoprene and $\alpha$-pinene in the presence of $\mathrm{NO}_{\mathrm{x}}$ and $\mathrm{SO}_{2}$, Environ. Sci. Technol., 40, 3807-3812, 2006.

Kleinman, L., Lee, Y., Springston, S., Nunnermacker, L., Zhou, X., Brown, R., Hallock, K., Klotz, P., Leahy, D., Lee, J., and Newman, L.: Ozone formation at a rural site in the southeastern United States, J. Geophys. Res.-Atmos., 99, 3469-3482, doi:10.1029/93JD02991, 1994.

Kourtchev, I., Copolovici, L., Claeys, M., and Maenhaut, W.: Characterization of atmospheric aerosols at a forested site in Central Europe, Environ. Sci. Technol, 43, 4665-4671, 2009.

Lanz, V. A., Alfarra, M. R., Baltensperger, U., Buchmann, B., Hueglin, C., and Prvt, A. S. H.: Source apportionment of submicron organic aerosols at an urban site by factor analytical modelling of aerosol mass spectra, Atmos. Chem. Phys., 7, 15031522, doi:10.5194/acp-7-1503-2007, 2007.

Liggio, J., Li, S. M., Vlasenko, A., Sjostedt, S., Chang, R., Shantz, N., Abbatt, J., Slowik, J. G., Bottenheim, J. W., Brickell, P. C., Stroud, C., and Leaitch, W. R.: Primary and secondary organic aerosols in urban air masses intercepted at a rural site, J. Geophys. Res.-Atmos., 115, D21305, doi:10.1029/2010JD014426, 2010.

Lim, Y. and Ziemann, P.: Chemistry of secondary organic aerosol formation from $\mathrm{OH}$ radical-initiated reactions of linear, branched, and cyclic alkanes in the presence of $\mathrm{NO}_{\mathrm{x}}$, Aerosol. Sci. Tech., 43, 604-619, 2009.
Liu, C., Huang, C., Shieh, S., and Wu, C.: Important meteorological parameters for ozone episodes experienced in the Taipei basin, Atmos. Environ., 28, 159-173, 1994.

Liu, S., Takahama, S., Russell, L. M., Gilardoni, S., and Baumgardner, D.: Oxygenated organic functional groups and their sources in single and submicron organic particles in MILAGRO 2006 campaign, Atmos. Chem. Phys., 9, 6849-6863, doi:10.5194/acp9-6849-2009, 2009.

Madronich, S., Chatfield, R. B., Calvert, J. G., Moortgat, G. K., Veyret, B., and Lesclaux, R.: A photochemical origin of acetic acid in the troposphere, Geophys. Res. Lett., 17, 2361-2364, 1990.

Maria, S., Russell, L., Turpin, B., and Porcja, R.: FTIR measurements of functional groups and organic mass in aerosol samples over the Caribbean, Atmos. Environ., 36, 5185-5196, 2002.

Maria, S., Russell, L., Gilles, M., and Myneni, S.: Organic aerosol growth mechanisms and their climate-forcing implications, Science, 306, 1921-1924, 2004.

Martin, P., Tuazon, E. C., Aschmann, S. M., Arey, J., and Atkinson, R.: Formation and atmospheric reactions of 4, 5-dihydro-2methylfuran, J. Phys. Chem. A, 106, 11492-11501, 2002.

Miracolo, M., Presto, A., Lambe, A., Hennigan, C., Donahue, N., Kroll, J., Worsnop, D., and Robinson, A.: Secondary organic aerosol formation from low-volatility organic vapors in motor vehicle emissions, Environ. Sci. Technol., 44, 1638-1643, 2010.

Morgan, W., Allan, J., Bower, K.,Highwood, E.J., Liu, D., McMeeking, G., Northway, M.,Williams, P., Krejci, R., and Coe, H.: Airborne measurements of the spatial distribution of aerosol chemical composition across Europe and evolution of the organic fraction, Atmos. Chem. Phys., 10, 4065-4083, doi:10.5194/acp10-4064-2010, 2010.

Ng, N. L., Canagaratna, M. R., Zhang, Q., Jimenez, J. L., Tian, J., Ulbrich, I. M., Kroll, J. H., Docherty, K. S., Chhabra, P. S., Bahreini, R., Murphy, S. M., Seinfeld, J. H., Hildebrandt, L., Donahue, N. M., DeCarlo, P. F., Lanz, V. A., Prévôt, A. S. H., Dinar, E., Rudich, Y., and Worsnop, D. R.: Organic aerosol components observed in Northern Hemispheric datasets from Aerosol Mass Spectrometry, Atmos. Chem. Phys., 10, 46254641, doi:10.5194/acp-10-4625-2010, 2010.

Paatero, P. and Tapper, U.: Positive matrix factorization: A nonnegative factor model with optimal utilization of error estimates of data values, Environmetrics, 5, 111-126, 1994.

Pekney, N., Davidson, C., Robinson, A., Zhou, L., Hopke, P., Eatough, D., and Rogge, W.: Major Source Categories for $\mathrm{PM}_{2.5}$ in Pittsburgh using PMF and UNMIX, Aerosol. Sci. Tech., 40, 910-924, 2006.

Pietrogrande, M. C., Mercuriali, M., Perrone, M. G., Ferrero, L., Sangiorgi, G., and Bolzacchini, E.: Distribution of $n$-Alkanes in the Northern Italy Aerosols: Data Handling of GC-MS Signals for Homologous Series Characterization, Environ. Sci. Technol, 44, 4232-4240, 2010.

Presto, A., Miracolo, M., Donahue, N., and Robinson, A.: Secondary organic aerosol formation from high- $\mathrm{NO}_{\mathrm{x}}$ photooxidation of low volatility precursors: n-alkanes, Environ. Sci. Technol, 44, 2029-2034, 2010.

Quinn, P., Bates, T., Coffman, D., Onasch, T., Worsnop, D., Baynard, T., De Gouw, J., Goldan, P., Kuster, W., Williams, E., Roberts, J. M., Lerner, B., Stohl, A., Pettersson, A., and Lovejoy, R. E.: Impacts of sources and aging on submicrom- 
eter aerosol properties in the marine boundary layer across the Gulf of Maine, J. Geophys. Res.-Atmos., 111, D23S36, doi:10.1029/2006JD007582, 2006.

Rogge, W. F., Hildemann, L. M., Mazurek, M. A., Cass, G. R., Simoneit, and B. R. T.: Sources of fine organic aerosol. 1. Charbroilers and meat cooking operations, Environ. Sci. Technol., 25, 1112-1125, 1991.

Rogge, W., Mazurek, M., Hildemann, L., Cass, G., and Simoneit, B.: Quantification of urban organic aerosols at a molecular level: identification, abundance and seasonal variation, Atmos. Environ., 27, 1309-1330, 1993.

Rolph, G.: Real-time Environmental Applications and Display sYstem (READY) Website (http://www.arl.noaa.gov/ready/hysplit4. html), NOAA Air Resources Laboratory, Silver Spring, Silver Spring, MD, USA, 2003.

Russell, L. M., Maria, S., and Myneni, S.: Mapping organic coatings on atmospheric particles, Geophys. Res. Lett., 29, 1779, doi:10.1029/2002GL014874, 2002.

Russell, L. M., Takahama, S., Liu, S., Hawkins, L., Covert, D., Quinn, P., and Bates, T.: Oxygenated fraction and mass of organic aerosol from direct emission and atmospheric processing measured on the R/VRonald Brownduring TEXAQS/GoMACCS 2006, J. Geophys. Res.-Atmos., 114, D00F05, doi:10.1029/2008JD011275, 2009a.

Russell, L. M., Bahadur, R., Hawkins, L., Allan, J., Baumgardner, D., Quinn, P., and Bates, T.: Organic aerosol characterization by complementary measurements of chemical bonds and molecular fragments, Atmos. Environ., 43, 6100-6105, 2009b.

Russell, L. M., Hawkins, L. N., Frossard, A., Quinn, P., and Bates, T.: Carbohydrate-like composition of submicron atmospheric particles and their production from ocean bubble bursting, Proc. Natl. Acad. Sci., 107, 6652, doi:10.1073/pnas.0908905107, 2010.

Russell, L. M., Bahadur, R., and Ziemann, P. J.: Identifying organic aerosol sources by comparing functional group composition in chamber and atmospheric particles, Proc. Natl. Acad. Sci., doi:10.1073/pnas.1006461108, 2011.

Satsumabayashi, H., Kurita, H., Yokouchi, Y., and Ueda, H.: Mono-and di-carboxylic acids under long-range transport of air pollution in central Japan, Tellus B, 41, 219-229, 1989.

Satsumabayashi, H., Kurita, H., Yokouchi, Y., and Ueda, H.: Photochemical formation of particulate dicarboxylic acids under long-range transport in central Japan, Atmospheric Environment. Part A. General Topics, 24, 1443-1450, 1990.

Sax, M., Zenobi, R., Baltensperger, U., and Kalberer, M.: Time resolved infrared spectroscopic analysis of aerosol formed by photo-oxidation of 1,3,5-trimethylbenzene and $\alpha$-pinene, Aerosol. Sci. Tech., 39, 822-830, 2005.

Schuetzle, D., Cronn, D., Crittenden, A. L., and Charlson, R. J.: Molecular composition of secondary aerosol and its possible origin, Environ. Sci. Technol., 9, 838-845, 1975.

Sullivan, A. and Weber, R.: Chemical characterization of the ambient organic aerosol soluble in water: 1 . Isolation of hydrophobic and hydrophilic fractions with a XAD-8 resin, J. Geophys. Res.Atmos., 111, D05314, doi:10.1029/2005JD006485, 2006.

Sullivan, R. and Prather, K.: Investigations of the diurnal cycle and mixing state of oxalic acid in individual particles in Asian aerosol outflow, Environ. Sci. Technol., 41, 8062-8069, 2007.

Surratt, J., Lewandowski, M., Offenberg, J., Jaoui, M., Kleindienst,
T., Edney, E., and Seinfeld, J.: Effect of acidity on secondary organic aerosol formation from isoprene, Environ. Sci. Technol., 41, 5363-5369, 2007.

Takahama, S., Gilardoni, S., Russell, L., and Kilcoyne, A.: Classification of multiple types of organic carbon composition in atmospheric particles by scanning transmission X-ray microscopy analysis, Atmos. Environ., 41, 9435-9451, 2007.

Takahama, S., Liu, S., and Russell, L.: Coatings and clusters of carboxylic acids in carbon-containing atmospheric particles from spectromicroscopy and their implications for cloud-nucleating and optical properties, J. Geophys. Res.-Atmos., 115, D01202, doi:10.1029/2009JD012622, 2010.

Talbot, R., Mao, H., and Sive, B.: Diurnal characteristics of surface level O3 and other important trace gases in New England, J. Geophys. Res.-Atmos., 110, D09307, doi:10.1029/2004JD005449, 2005.

Tan, Y., Perri, M., Seitzinger, S., and Turpin, B.: Effects of Precursor Concentration and Acidic Sulfate in Aqueous Glyoxal$\mathrm{OH}$ Radical Oxidation and Implications for Secondary Organic Aerosol, Environ. Sci. Technol., 43, 8105-8112, 2009.

Turpin, B., Huntzicker, J., Larson, S., and Cass, G.: Los Angeles summer midday particulate carbon: primary and secondary aerosol, Environ. Sci. Technol., 25, 1788-1793, 1991.

Turpin, B., Saxena, P., and Andrews, E.: Measuring and simulating particulate organics in the atmosphere: problems and prospects, Atmos. Environ., 34, 2983-3013, 2000.

Ulbrich, I. M., Lechner, M., and Jimenez, J. L.: AMS Spectral Database, http://cires.colorado.edu/jimenez-group/AMSsd, access:10Feb2010, 2007.

Ulbrich, I. M., Canagaratna, M. R., Zhang, Q., Worsnop, D. R., and Jimenez, J. L.: Interpretation of organic components from Positive Matrix Factorization of aerosol mass spectrometric data, Atmos. Chem. Phys., 9, 2891-2918, doi:10.5194/acp-9-2891-2009, 2009.

Wang, G., Niu, S., Liu, C., and Wang, L.: Identification of dicarboxylic acids and aldehydes of $\mathrm{PM}_{10}$ and $\mathrm{PM}_{2.5}$ aerosols in Nanjing, China, Atmos. Environ., 36, 1941-1950, 2002.

Wang, G., Kawamura, K., Xie, M., Hu, S., Gao, S., Cao, J., An, Z., and Wang, Z.: Size-distributions of n-alkanes, PAHs and hopanes and their sources in the urban, mountain and marine atmospheres over East Asia, Atmos. Chem. Phys., 9, 8869-8882, doi:10.5194/acp-9-8869-2009, 2009.

Warneck, P.: In-cloud chemistry opens pathway to the formation of oxalic acid in the marine atmosphere, Atmos. Environ., 37, 2423-2427, 2003.

Williams, B. J., Goldstein, A. H., Kreisberg, N. M., and Hering, S. V.: In situ measurements of gas/particle-phase transitions for atmospheric semivolatile organic compounds, Proc. Natl. Acad. Sci., doi:10.1073/pnas.0911858107, 2010.

Yu, J., Griffin, R., Cocker, D., Flagan, R., Seinfeld, J., and Blanchard, P.: Observation of gaseous and particulate products of monoterpene oxidation in forest atmospheres, Geophys. Res. Lett., 26, 1145-1148, doi:10.1029/1999GL900169, 1999.

Yu, J., Huang, X., Xu, J., and Hu, M.: When aerosol sulfate goes up, so does oxalate: implication for the formation mechanisms of oxalate, Environ. Sci. Technol., 39, 128-133, 2005.

Zhang, Q., Alfarra, M., Worsnop, D., Allan, J., Coe, H., Canagaratna, M., and Jimenez, J.: Deconvolution and quantification of hydrocarbon-like and oxygenated organic aerosols based on 
aerosol mass spectrometry, Environ. Sci. Technol., 39, 49384952, 2005.

Zhang, Q., Jimenez, J., Worsnop, D., and Canagaratna, M.: A case study of urban particle acidity and its influence on secondary organic aerosol, Environ. Sci. Technol., 41, 3213-3219, 2007a.

Zhang, Q., Jimenez, J. L., Canagaratna, M. R., Allan, J. D.,Coe, H., Ulbrich, I.,Alfarra, M. R.,Takami, A., Middlebrook, A. M., Sun, Y. L., Dzepina, K., Dunlea, E., Docherty, K., DeCarlo, P. F., Salcedo, D., Onasch, T., Jayne, J. T., Miyoshi, T., Shimono, A., Hatakeyama, S., Takegawa, N., Kondo, Y., Schneider, J., Drewnick, F., Borrmann, S., Weimer, S., Demerjian, K., Williams, P., Bower, K., Bahreini, R., Cottrell, L., Griffin, R. J., Rautiainen, J., Sun, J. Y., Zhang, Y. M., and Worsnop, D. R.: Ubiquity and dominance of oxygenated species in organic aerosols in anthropogenically-influenced Northern Hemisphere midlatitudes, Geophys. Res. Lett., 34, L13801, doi:10.1029/2007GL029979, 2007b.
Zhang, Y. Y., Müller, L., Winterhalter, R., Moortgat, G. K., Hoffmann, T., and Pöschl, U.: Seasonal cycle and temperature dependence of pinene oxidation products, dicarboxylic acids and nitrophenols in fine and coarse air particulate matter, Atmos. Chem. Phys., 10, 7859-7873, doi:10.5194/acp-10-7859-2010, 2010. 